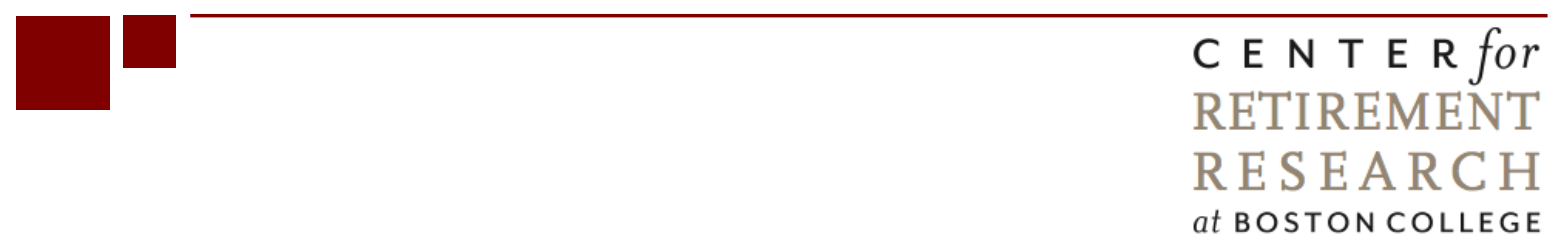

\title{
THE POTENTIAL IMPACT OF THE GREAT RECESSION ON FUTURE RETIREMENT INCOMES
}

\author{
Barbara A. Butrica, Richard W. Johnson, and Karen E. Smith
}

CRR WP 2011-9

Date Released: May 2011

Date Submitted: May 2011
Center for Retirement Research at Boston College
Hovey House
140 Commonwealth Avenue
Chestnut Hill, MA 02467

Tel: 617-552-1762 Fax: 617-552-0191

http://crr.bc.edu

Barbara Butrica and Karen Smith are senior research associates at the Urban Institute. Richard Johnson is a senior fellow at the Urban Institute. The research reported here was performed pursuant to a grant from the U.S. Social Security Administration (SSA) funded as part of the Retirement Research Consortium (RRC). The opinions and conclusion expressed are solely those of the authors and do not represent the opinions or policy of SSA, any agency of the federal government, the RRC, the Urban Institute, or Boston College.

(C) 2011, by Barbara A. Butrica, Richard W. Johnson, and Karen E. Smith. All rights reserved. Short sections of text, not to exceed two paragraphs, may be quoted without explicit permission provided that full credit, including (C) notice, is given to the source. 


\title{
About the Center for Retirement Research
}

The Center for Retirement Research at Boston College, part of a consortium that includes parallel centers at the University of Michigan and the National Bureau of Economic Research, was established in 1998 through a grant from the Social Security Administration. The Center's mission is to produce first-class research and forge a strong link between the academic community and decision-makers in the public and private sectors around an issue of critical importance to the nation's future. To achieve this mission, the Center sponsors a wide variety of research projects, transmits new findings to a broad audience, trains new scholars, and broadens access to valuable data sources.

\author{
Center for Retirement Research at Boston College \\ Hovey House \\ 140 Commonwealth Avenue \\ Chestnut Hill, MA 02467 \\ phone: 617-552-1762 fax: 617-552-0191 \\ e-mail: crr@bc.edu \\ crr.bc.edu
}

\author{
Affiliated Institutions: \\ The Brookings Institution \\ Massachusetts Institute of Technology \\ Syracuse University \\ Urban Institute
}




\begin{abstract}
This study uses DYNASIM3, the Urban Institute’s dynamic microsimulation model, to examine the long-run effects of the Great Recession on the future retirement incomes of working-age individuals in 2008. It compares a baseline scenario that incorporates the historic and projected effects of high unemployment and lower wages from the recession with a no-recession scenario that assumes the recession had not occurred.

The results show that the recession will reduce average annual incomes at age 70 by 4.3 percent, or $\$ 2,300$ per person. This drop results almost entirely from the anemic wage growth that occurred during the recession, which the model assumes will permanently reduce future wages. Employment declines will have little effect on future aggregate retirement incomes because most workers remained employed during the recession and the losses that occurred are generally inconsequential when averaged over an entire career. Retirement incomes will fall most for high-socioeconomic-status groups, who have the most to lose, but relative income losses will not vary much across groups. Those workers who were youngest when the recession began will be hit hard. They are most likely to have lost their jobs and the impact of lower wages will accumulate over much of their working lives. But retirement incomes will also fall substantially for those in their late fifties in 2008, because the drop in the economy-wide average wage will lower the index factor in the Social Security benefit formula, permanently reducing their annual benefits. Also, many workers who lost jobs late in life will never become reemployed.
\end{abstract}




\section{Introduction}

The Great Recession, as many analysts dubbed the 2007-2009 economic downturn, lived up to its name. Millions of jobs were lost, unemployment soared, and wages stagnated for those able to stay employed. Many jobless Americans were out of work for more than a year. As incomes fell, families struggled to make ends meet and poverty rates surged. Declining tax revenues and expanding public expenditures to support unemployed workers and stimulate the economy swelled the federal deficit and squeezed state and local governments. And in 2011 the end was not yet in sight. Although the National Bureau of Economic Research declared the recession over in 2009, the labor market remained weak in 2011, with the unemployment rate near 9 percent in the early months of the year. Many analysts predict that unemployment will stay above its prerecession level for years (Eberts 2011).

In addition to creating financial hardship for millions of working families, the Great Recession may also erode economic security for future retirees. Earlier research showed that the 2008 stock market crash could erode retirement security for high-income people most likely to hold equities (Butrica, Smith, and Toder 2009, 2010). High unemployment could reduce future retirement incomes for a broader segment of the population. In addition to reducing earnings, job loss lowers Social Security and pension credits and leaves workers with less income to set aside for retirement. Many workers are also forced to dip into their 401(k) accounts and other retirement savings when they lose their jobs (Butrica, Zedlewski, and Issa 2010). Because unemployment rates increased most sharply for low-wage workers, the recession might hit their future retirement incomes especially hard. But higher-wage workers could also be affected, because they are more likely to have pension coverage and retirement savings that might be jeopardized. Impacts might be severe for older workers, who have little time before retirement to recoup earnings. However, retirement incomes could fall sharply for younger workers, especially if the wage stagnation that occurred in the recession translates into permanently reduced earnings for their entire careers.

This report uses the Urban Institute's dynamic microsimulation model to examine the impact of the Great Recession on future retirement incomes. The analysis projects average incomes to age 70 for adults who were age 25 to 64 in 2008, and compares them to what retirees would have received if the recession had not occurred. The baseline simulations use the Social 
Security trustees' assumptions from 2010, and the no-recession simulations use their assumptions from 2008, before the labor market had weakened or the recession became apparent.

The results show that the Great Recession will modestly reduce future retirement incomes. The drop results almost entirely from the anemic wage growth that occurred during the recession, which our model assumes will permanently reduce future wages. Employment declines will have little effect on future aggregate retirement incomes because most workers remained employed during the recession and the losses that occurred are generally inconsequential when averaged over decades-long careers. Retirement incomes will fall most sharply for high-socioeconomic-status groups, who have the most to lose, but relative income losses will not vary much across groups. Those workers who were youngest when the recession began will be hit hard. They are most likely to have lost their jobs and the impact of lower wages will accumulate over their entire careers. But retirement incomes will also fall substantially for those in their late fifties in 2008, because the drop in the economy-wide average wage will lower the index factor in the Social Security benefit formula, permanently reducing their annual benefits.

\section{Background: The Great Recession}

By many measures the Great Recession was the worst economic downturn since the Great Depression. It lasted 16 months, the longest recession of the post-World-War-II period. Gross domestic product fell 2.6 percent in 2009, the greatest single-year decline since 1938 (Bureau of Economic Analysis 2011). Between December 2007 and February 2010, the economy shed 8.8 million private-sector jobs (Bureau of Labor Statistics [BLS] 2011a).

The drop in economic activity left millions of Americans out of work. The unemployment rate peaked at 10.1 percent in October 2009 (figure 1). Although this was not the highest unemployment rate since the Great Depression - that occurred in November and December 1982, when it reached 10.8 percent — it was the highest rate since the early months of 1983. Additionally, the 5.5 percentage point increase in the unemployment rate over the course of the recession marked the strongest surge in unemployment of the postwar period (Elsby Hobijn, and Sahin 2010). The portion of Americans touched by unemployment at some point during the recession was even higher. About a fifth of adults in RAND's American Life Panel 
were unemployed at some point between November 2008 and October 2009 (Hurd and Rohwedder 2010). In a summer 2010 survey, nearly three-quarters of workers reported that they or their family members or close friends had lost a job in the past three years (Godofsky, Van Horn, and Zukin 2010).

Unemployment hit certain groups much more than others. Table 1 reports average monthly unemployment rates in 2010 by sex, education, age, race, and Hispanic origin. Unemployment rates were higher for men than women (10.5 versus 8.6 percent). Unemployment was also more common among younger workers than older workers, those with no more than a high school diploma than college graduates, and African Americans and Hispanics than nonHispanic whites. For some demographic groups, unemployment rates reached astronomical levels. Among African American men age 20 to 24, about half of those who did not complete high school and nearly a third of those with only a high school diploma were unemployed in 2010. The unemployment rate approached one-quarter for African American men age 25 to 34 who completed high school but never attended college. By contrast, only about 4 percent of nonHispanic white men age 35 to 49 who completed four or more years of college were unemployed. These same patterns were evident in previous recessions (Farber 2005).

The official unemployment rate understates the recession's impact on the labor market, because it counts only those who are not working at all and continue actively searching for work. It excludes part-time workers who cannot find full-time work and nonworking individuals who dropped out of the labor force because they became discouraged by their poor job prospects. The underemployment rate, which combines these groups with the unemployed, substantially exceeds the unemployment rate, especially for women (many of whom work part time).

Underemployment varies across demographic groups in roughly the same way as unemployment, with rates especially high for younger workers, African Americans, Hispanics, and those with limited education (table 2). About three-fifths of African American women age 20 to 24 who did not complete high school and two-fifths of their counterparts with only high school diplomas were underemployed in 2010. For African American men in the same age group, 2010 underemployment reached about 67 percent for those who did not complete high school and about 48 percent for those who completed high school but did not attend college. As with the 
unemployment rate, the underemployment rate was quite low for non-Hispanic white college graduates.

One of the especially troubling aspects of the Great Recession is the high prevalence of long-term unemployment. In 2010, 43 percent of the unemployed had been out of work for more than six months (Johnson and Park 2011b), a larger share than in any previous post-war recession (Vroman 2010). A follow-up survey of workers unemployed in August 2009 found that only 21 percent were working seven months later, in March 2010 (Borie-Holtz, Van Horn, and Zukin 2010). About two-thirds were still looking for work, and about one-eighth had dropped out of the labor force. Of those reemployed, 65 percent searched for at least seven months; 28 percent looked for more than a year. Reemployment rates were lower among low-wage workers and those with limited education. Older unemployed workers faced special difficulty finding work. Tracking workers in the U.S. Census Bureau's Survey of Income and Program Participation (SIPP) who lost a job between mid-2008 and the end of 2009, Johnson and Park (2011a) found that only a quarter of those age 50 and older found work within 12 months, compared with more than a third age 25 to 34 . The housing bust made unemployment worse, because many jobless Americans were unable to sell their homes to move to areas of the country with better job prospects, especially if their mortgage debt exceeded the value of their home (Ferraira, Gyourko, and Tracy 2010).

Partly because so many of the unemployed have been out of work for so long, the recession has taken a tremendous toll on workers who lost their jobs. About three quarters of unemployed workers in a summer 2010 survey said the recession had a major impact on their lives, slightly more than half described their financial situation as poor, and about a tenth filed for bankruptcy (Godofsky, Van Horn, and Zukin 2010). Unemployed workers who experienced a drop in earnings cut their monthly spending by 12 percent, on average (Hurd and Rohwedder 2010). Of those unemployed for at least seven months in March 2010, 70 percent had spent money from their savings, 56 percent borrowed money from family and friends, and 24 percent missed mortgage or rent payments (Borie-Holtz, Van Horn, and Zukin 2010). Nearly half added to their credit card debt, a common response to job loss in previous recessions (Sullivan 2008). The recession also left an emotional mark on families. In 2010, 18 percent of unemployed 
workers had sought professional help in the past year for depression or a stress-related disorder (Godofsky, Van Horn, and Zukin 2010).

Those who remained employed did not emerge from the recession unscathed. Wage growth stagnated during the Great Recession, as in previous economic downturns (Solon, Barsky, and Parker 1994). Nominal wages in the private sector increased just 1.6 percent between the second quarters of 2008 and 2009, and again between the second quarters of 2009 and 2010 (Mishel and Shierholz 2010). By contrast, they grew 3.4 percent between 2006 and 2007, before the recession began. Measured in real terms, wages in the private sector declined by 1.1 percent between the second quarters of 2007 and 2008.

As unemployment surged and wages stagnated, household wealth fell and poverty worsened. About three-fifths of Americans experienced a decline in wealth between 2007 and 2009, and a quarter had their wealth cut in half (Bricker et al. 2011). Between September 2008 and the second quarter of 2009, half of households with employer-based pension plans, individual retirement accounts (IRAs), mutual funds, and directly held stocks saw their holdings in those assets decline by more than 30 percent (Christelis, Georgarakos, and Jappelli 2011). The number of Americans living in poverty increased 17 percent between 2007 and 2009, and the 2009 poverty rate reached 14.3 percent (DeNavas-Walt, Proctor, and Smith 2010).

\section{Potential Impact on Future Retirement Incomes}

It is too soon to observe how the Great Recession affected workers' future retirement incomes, but the impact could be significant. Retirement incomes depend largely on how much people earn in their working years. Higher lifetime earnings translate into larger Social Security benefits, although the relationship is somewhat complicated. To compute benefits, Social Security indexes the worker's earnings to changes in the economy-wide average wage. Only earnings below the taxable maximum (\$106,800 in 2011) are counted. The basic benefit is based on the average of the top 35 years of indexed earnings. Those who begin collecting before the system's full retirement age (66 for those currently age 62) receive less than their basic benefit each month, whereas those who wait until after the full retirement age get more. But the benefit formula is progressive. It replaces 90 percent of the first dollars of average monthly indexed earnings, but only 15 percent of earnings above a certain amount. Spousal and survivor benefits 
further weaken the relationship between earnings and benefits. For example, workers may receive half of their spouse's benefits instead of collecting based on their own earnings if that would generate a higher benefit.

Lifetime earnings also affect pension incomes and retirement wealth. Defined-benefit (DB) pension plans typically tie monthly payments to final average pay and years of service. Workers who participate in defined contribution (DC) retirement plans at the workplace typically contribute a portion of their pay each period, with their employers often matching their contributions. As earnings increase, workers are generally better able to set money aside for retirement in other ways as well, such as by investing more in IRAs or other financial instruments.

The Great Recession might depress future retirement incomes. When unemployed, workers do not accumulate Social Security or pension credits, and they do not contribute to DC retirement plans. Many are forced to dip into their savings and 401(k) plans to meet current consumption needs, leaving fewer funds available in retirement. Even those workers who remain employed may be seriously affected, because wages did not grow much during the recession. Lower wage growth reduces Social Security and pension benefits, and limits savings ability. Some unemployed workers, however, might be able to recoup most of the retirement wealth lost during the recession, especially those who were young when the downturn began. After all, a year or two of lost work may be inconsequential over a 40 -year career.

The recession's effect on retirement security might vary across demographic groups. Low-wage workers may be especially vulnerable, because they were most likely to lose their jobs. Higher-income workers might be hit hard, because they are more likely to have pension coverage and retirement savings that could be affected. Impacts might be severe for older workers, who have little time before retirement to recoup earnings. Retirement incomes could also fall sharply for younger workers, especially if the wage stagnation that occurred in the recession translates into permanently reduced earnings for their entire careers.

\section{Methods}

To assess the impact of the Great Recession on future retirement security, we project incomes at age 70 for adults age 25 to 64 in 2008 and compare them to what older adults would have 
received had the recession not occurred. We focus on income at age 70 because the vast majority of adults have retired by then, so differences in current employment will not affect projected income differentials much. The impact of high unemployment on future retirement incomes will likely depend on one's stage of the life course when the recession hits. To capture these differences, the analysis compares outcomes by 10-year cohorts, ranging from those age 25 to 34 in 2008 (who turn 70 between 2044 and 2053) to those age 55 to 64 in 2008 (who turn 70 between 2014 and 2023).

\section{DYNASIM3}

Projections come from the Urban Institute's Dynamic Simulation of Income Model (DYNASIM3). DYNASIM3 starts with a self-weighting sample of 103,072 individuals from the 1990 to 1993 panels of SIPP and ages this starting sample in yearly increments to 2085, using parameters estimated from longitudinal data sources. DYNASIM3 then projects demographic and economic changes annually from 1993 to 2085 . The model integrates many important trends and group-level differences in life course processes, including birth, death, schooling, leaving home, first marriage, remarriage, divorce, disability, work, retirement, and earnings. It projects the major sources of income and wealth annually from age 15 until death, including employment, earnings, Social Security benefits, benefits from employer-sponsored DB pensions, Supplemental Security Income (SSI), retirement accounts (DC plans, IRAs, and Keoghs), and other assets (saving, checking, money market, CD, stocks, bonds, equity in businesses, vehicles, and non-home real estate, less unsecured debt).

DYNASIM3's employment, earnings, and inflation projections are aligned to the Social Security trustees' intermediate-cost projections. ${ }^{1}$ DYNASIM3 projects the likelihood that an individual works each year as a function of age, sex, race and ethnicity, education, health and disability status, geographic region, marital status, student status, number of young children, spouse characteristics (employment, age, disability, and education), immigrant status, Social Security benefit status, cohort, and the state-specific unemployment rate. The likelihood also includes an estimated individual-specific error term that captures non-varying individual

\footnotetext{
${ }^{1}$ Fertility, disability, mortality, and net immigration projections in DYNASIM3 are also aligned with the trustees' projections.
} 
preferences that are independent of observed characteristics. The model classifies an individual as employed if his or her expected probability of working exceeds a given random number. The selection criteria is adjusted so that our employment projections for men and women within particular age groups hit the trustees' targets. ${ }^{2}$

DYNASIM3 uses a similar set of explanatory variables to assign hourly wages and annual hours of employment to those projected to work. Annual earnings are the product of the hourly wage and annual hours worked. DYNASIM3 adjusts the underlying predicted annual wage for real wage growth based on the trustees' economic assumptions. It also aligns the annual earnings of workers to hit the trustees' annual earnings targets.

The underlying price and wage targets affect various other projections including the Social Security wage base (the taxable maximum), the indexing of wages for the calculation of Social Security benefits, SSI benefit parameters, stock and bond rates of return, and interest rates. Changes in economic conditions also affect retirement and Social Security benefit claiming, as well as marriage, divorce, fertility, and schooling outcomes.

DYNASIM3 projects income from various other sources to generate a measure of total household income. Social Security income is computed based on the benefit formula, projected lifetime earnings, and an equation projecting benefit take-up. DYNASIM3 projects payments from employer-sponsored DB plans, cash balance (CB) plans, and retirement accounts based on equations of job change, retirement plan coverage and participation, and plan contributions. The model measures income from retirement accounts and financial assets each year as the real actuarially fair annuity payment that a family would receive if it annuitized 80 percent of its wealth. Additional information about the projections are provided in the appendix.

We examine the impact of the Great Recession on lifetime employment and several income measures, including own lifetime earnings, per capita household lifetime earnings, and per capita household income at age 70. Individuals are considered employed in a given year if they have any earnings, even if they worked relatively few hours because they were unemployed for part of the year. (The Social Security trustees follow the same convention when setting their employment targets.) As a result, employment rates calculated in DYNASIM3 do not match

\footnotetext{
${ }^{2}$ The random error term follows an AR1 process so that random shocks include both a new and lagged effect.
} 
those from BLS, which are annual averages of monthly employment. ${ }^{3}$ Own lifetime earnings is annual earnings in 2007 price-adjusted dollars, averaged from age 22 to 62. Per capita household earnings, which we term shared lifetime earnings, is computed as half of the husband's and wife's earnings in years when an individual is married and own earnings in years when single. As with own lifetime earnings, shared lifetime earnings are price-indexed to 2007 dollars and averaged from age 22 to 62 . Both measures include years with zero earnings. Per capita household income includes all income received by the individual and spouse, divided by two if married. It excludes income of other household members. Because income and asset distributions are highly skewed, we drop individuals in the top 1 percent of the income distribution to lessen the impact of these outliers on reported means. Unless otherwise noted, all financial amounts are reported in constant 2007 dollars (adjusted by the projected change in the Consumer Price Index).

\section{Simulating the Impact of the Great Recession}

We estimate the impact of the Great Recession on future retirement incomes by comparing outcomes under two DYNASIM3 simulations based on different alignment adjustments. Our baseline simulation uses the Social Security trustees' 2010 assumptions (Social Security Board of Trustees 2010), released in August of that year, which account for the actual and projected effects of high unemployment and lower wages from the Great Recession. They fully capture the trustees' assessment of how the recession will affect future employment and earnings. Our alternative scenario, designed to simulate outcomes if the recession had not occurred, is based largely on the trustees' 2008 assumptions (Social Security Board of Trustees 2008), released in March of that year, before the recession had become apparent or had weakened the labor market very much.

One complication is that some differences between the 2008 and 2010 trustees' assumptions were unrelated to the recession. For example, the trustees changed their assumptions about mortality and immigration after 2008. They also increased their long-range real wage growth assumptions from 1.1 percent per year to 1.2 percent per year. The implementation of the

\footnotetext{
${ }^{3}$ Another difference is that DYNASIM3 includes institutionalized adults, overseas military personnel, and residents of U.S. territories, whereas BLS uses the civilian noninstitutionalized U.S. resident population.
} 
Affordable Care Act, signed by President Obama in March 2010, is expected to reduce employers' health care spending, which in turn will boost earnings. To isolate the changes in the trustees' assumptions between 2008 and 2010 related to the recession, we use adjusted 2008 targets in the no-recession simulation. That simulation uses the 2008 trustees' employment and disability onset rates and assumes that real wages grow through 2010 at the rate assumed by the trustees in 2008, after which they grow at the higher rates assumed by the trustees in 2010. Both the baseline and no-recession simulations, then, capture the expected impact of health reform on projected wage growth. The no-recession scenario also uses the trustees' 2008 price growth series through 2010 and aligns price growth with the trustees' 2010 assumptions for later years. As a result, the no-recession simulation includes permanently higher average earnings and price targets than the baseline simulation in all years after 2007. All other parameters in the norecession simulation rely on the 2010 trustees' assumptions.

We also consider a third scenario identical to the no-recession scenario except for the assumptions regarding wages and prices. It uses the wage and price targets from the 2008 trustees' report through 2010, and then, based on linear interpolation, assigns wage and price targets between 2011 and 2022 so that they slowly converge with those from the 2010 trustees' report by 2023. In this low-wage-growth scenario, then, wages after 2022 are at the relatively low levels that prevail in the baseline scenario but employment rates between 2008 and 2023 remain at the relatively high no-recession-scenario levels, enabling us to isolate the employment effects of the recession from the combined effects of employment, price, and wage changes.

Figure 2 shows actual and projected employment rates at age 16 to 64 under the baseline scenario. The impact of the Great Recession is evident. Between 2007 and 2010, employment rates fall from 82 to 75 percent for men and from 77 to 71 percent for women. Employment rates gradually recover after 2010, stabilizing in 2016 at about 80 percent for men and 74 percent for women. Appendix tables 1 and 2 break down actual and projected employment rates by age, for men and women, showing rates under the baseline scenario and how they declined because of the recession. For prime-age workers (age 25 to 49), the recession reduced 2010 employed rates by about 5 percentage points for men and 2 percentage points for women. The impacts were smaller at older ages. At age 55 to 59, for example, the recession reduced 2010 employment rates by only about 2 percentage points for men and 1 percentage point for women. Younger adults were 
hit much harder by the recession, however. Employment rates fell about 25 percentage points in 2010 for men age 18 to 19, and do not fully recover until 2024.

Figure 3 shows the projected earnings targets for the three scenarios, in nominal dollars. In the baseline scenario, earnings stagnate in 2008 and 2009, but continue to grow at about 4 percent per year in the no-recession scenario. By the time the growth rates converge again in the two scenarios in 2010, average earnings in the no-recession scenario exceed those in the baseline scenario by 6.4 percent, a differential that persists throughout the projection period. The absolute value of the wage differential in the two scenarios grows (in nominal dollars) from about $\$ 2,700$ in 2010 to $\$ 4,200$ in 2020 to $\$ 6,100$ in 2030 . The projected price targets do not differ much across the three scenarios (figure 4 ).

\section{Results}

We describe the short-run impact of the recession on employment rates in 2010 and the longerterm consequences for lifetime work histories and income at age 70 . Tabulations show how the recession will affect different sources of retirement income and how outcomes vary by education, demographics, lifetime earnings histories, and income levels. We also discuss how the recession's impact would differ if wages were to grow slowly even if the recession had not occurred.

\section{The Recession's Impact on Employment}

Table 3 shows DYNASIM3 employment rates in 2010 (when unemployment peaked) under the baseline scenario and the absolute and percentage change relative to the no-recession scenario. In 2010, DYNASIM3 estimates that 71.1 percent of 25- to 64-year-olds were working (had earnings), 3.4 percentage points (4.6 percent) below the share that would have been employed had the recession not occurred. The hardest hit among this age group were 35- to 44-year-olds, whose employment rate declined by 3.9 percentage points ( 5.0 percent). In contrast, those age 55 to 64 , whose employment rate declined by only 2.5 percentage points ( 4.0 percent), were least affected. Men, blacks, and Hispanics; those who did not complete high school; and those with intermittent employment histories and lower wages were generally hit harder by the recession 
than others. In the youngest age group, employment rates fell by 10.9 percent for those lacking high school diplomas, but only 3.4 percent for college graduates.

Projecting outcomes to age 70 show the effects of the recession compounded over a lifetime. Although it reduced employment rates by about 3 percentage points in 2010 - at the peak of the downturn in the labor market - most workers retained their jobs or received at least some earnings in the year they became unemployed. As a result, the average number of years worked between age 22 and 62 will decline by less than 1 percent for all cohorts (table 4). Among the youngest age group, 66 percent will work 30 or more years over their lifetimes. This share is only 0.5 percentage points less than what it would have been had the recession not occurred. The recession will have virtually no impact on lifetime work years for those closest to retirement when the downturn began.

\section{Projected Incomes for Future Retirees}

Although the Great Recession will not shorten work lives, it will reduce average own lifetime earnings by $\$ 1,200$ - a decline of about 3 percent - because the economic downturn interrupted the growth in hourly wages (table 5). The impact will be greater for workers who were relatively young in 2008 and will spend much of their careers in the new, lower-wage labor market, and smaller for older workers who will spend few years in the less-inviting labor market. For example, the recession will reduce average own lifetime earnings 4.8 percent for those age 25 to 34 in 2008, but only 0.7 percent for those age 55 to 64 . Results are similar for husbands' and wives' shared lifetime earnings.

The recession will reduce Social Security benefits in two ways. Because Social Security benefits are based on the average of the highest 35 years of earnings, the decline in annual earnings after 2008 will directly lower future benefits. However, Social Security benefits will receive an additional hit because they are indexed to the economy-wide average wage in the year the beneficiary turns age 60 . Strong growth in average wages before age 60 raises future Social Security benefits, even for those whose own wages did not increase much, because the indexing

means that all earnings received before age 60 count more in the benefit formula than they would if average wages grew more slowly. Our baseline scenario assumes that the recession will permanently reduce earnings after 2008, which lowers the index factor in the Social Security 
benefit formula for everyone who turns 60 after 2008. In terms of Social Security, then, the recession effectively reduces even earnings received before 2008. As a result, future Social Security benefits will generally decline more sharply than lifetime earnings, especially for those approaching age 60 in 2008. Average own Social Security benefits will drop 1.4 percent for those age 55 to 64 in 2008 and 3.8 percent for those age 45 to 54, about twice the decline in lifetime earnings. ${ }^{4}$ For those age 25 to 34 who will spend nearly their entire careers in the postrecession labor market, the percentage decline in Social Security benefits roughly equals the percentage decline in lifetime earnings.

The recession will also affect retirement income outside of Social Security. Reduced earnings will lower wealth in employer pension and retirement plans and limit workers' ability to save outside of employment plans. Unemployed workers may be forced to dip into their retirement savings at relatively young ages to meet current consumption needs. It will also reduce post-retirement earnings.

Table 6 reports projected average per capita household income at age 70 . The recession will reduce future annual retirement income 4.3 percent (or $\$ 2,300$ per person) for adults age 25 to 64 in 2008. Incomes will drop 4.1 percent (or $\$ 2,000$ per person) for those closest to retirement when the recession hit, and by 4.9 percent (or $\$ 3,000$ per person) for those farthest from retirement. For the oldest group (those age 55 to 64 in 2008), average retirement incomes will drop more steeply than average Social Security benefits primarily because their age-70 earnings will fall 9.0 percent and their income from assets outside of pension and retirement plans will fall about 4.7 percent. Earnings at age 70 will drop so much for this age group because many lost their jobs late in life and will never become reemployed. DYNASIM3 projects that the recession will reduce age-70 employment rates by 2.3 percentage points for those age 55 to 64 in 2008 , but by only 0.2 percentage points for later cohorts (not shown). Wealth outside of pension plans falls for those near retirement when the recession hit because the recession forced many to dip into their savings to meet current consumption needs, and they have little time to recoup their

\footnotetext{
${ }^{4}$ Some people in the oldest age group turned 60 before 2008. The recession will not affect their Social Security benefits much.
} 
lost savings. For the youngest adults in 2008, the recession depresses overall retirement income by about the same percentage as Social Security benefits.

The recession's impact on income sources varies across the income distribution. Retirees in the bottom income quintile get most of their household income from Social Security benefits (around 70 percent). As a result, the projected drop in Social Security benefits for these retirees accounts for nearly the entire decline in their income at age 70. In contrast, retirees in the top income quintile get relatively little of their household income from Social Security benefits (around 15 percent), so the projected benefit decline explains only part of their total income losses. Although they will receive more Social Security benefits than lower-income retirees (despite the program's progressivity) and the recession will reduce their benefits more, this cut will account for only about 15 percent of the total income decline (averaged across all cohorts). Instead, the projected decline in household income for the highest-income retirees is driven mostly by drops in income from nonpension assets and earnings at 70. For example, the youngest age group is projected to lose $\$ 2,800$ (37 percent of total losses) in nonpension asset income and $\$ 1,500$ (20 percent of the total) in earnings, while the oldest age group is projected to lose $\$ 2,400$ (41 percent of the total) in nonpension asset income and $\$ 2,600$ (45 percent of the total) in earnings.

The recession-induced decline in household income will increase the number of Americans living in or near poverty at age 70 . Table 7 reports the number and percentage of adults surviving to age 70 with incomes below 100 percent and 125 percent of the federal poverty level (FPL). We focus on those below the higher threshold because the FPL is quite low and many with incomes that slightly exceed it struggle financially. Moreover, the official poverty measure does not fully capture households' health care spending needs, a particular concern for many older Americans. The National Academy of Sciences developed a revised poverty threshold that better accounts for out-of-pocket spending (Citro and Michael 1995). The 2009 poverty rate for adults age 65 and older under this revised measure was about equal to the share with incomes below 125 percent of the official poverty threshold, suggesting that 125 percent of the FPL is an appropriate indicator for financial hardship at older ages (DeNavas-Walt, Proctor, and Smith 2010; Short 2010). 
Across the four cohorts we examine, the share of adults with incomes below 125 percent of the FPL at age 70 will increase 7.4 percent because of the recession. The impact will grow over time, increasing about 6 percent for those closest to retirement in 2008 and nearly 10 percent for the youngest group. Among those age 25 to 64 in 2008, the recession will leave an additional 711,000 adults with incomes below 125 percent of the FPL. ${ }^{5}$

\section{Variation in Projected Outcomes by Individual Characteristics}

Table 8 shows how the recession's impact on average projected per capita household income at age 70 varies across the population. Although employment rates fell most dramatically during the recession among those with the least education and earnings, these groups will not experience the sharpest declines in future retirement incomes. Instead, incomes at age 70 will fall most (in absolute terms) for those with the highest incomes, who have most to lose. Among the youngest age group, for example, those in the top income quintile will lose $\$ 7,500$ per person annually, while those in the bottom income quintile will lose only $\$ 400$ per person annually. The recession will also sharply cut retirement incomes for college graduates, non-Hispanic whites, adults with 30 or more years of work experience, and those collecting Social Security benefits as retired workers, spouses, or survivors (not as disabled workers). The recession-induced earnings decline will reduce future income from pensions, retirement accounts, and other assets for these groups. Less affluent groups will experience smaller declines, because relatively few would receive much income from pensions and other assets even if the recession had not occurred.

In relative terms, however, high-socioeconomic-status groups will not lose much more income than less privileged groups, because the large absolute losses for affluent groups represent only a small share of their total income. Within the youngest age group, the recession will reduce age-70 incomes for the highest-income retirees by 4.7 percent, compared with 3.5 percent for the lowest-income retirees. Although the recession will cut future incomes for highsocioeconomic-status groups, they will remain much better off than others.

\footnotetext{
${ }^{5}$ Poverty rates in DYNASIM3 are lower than the official poverty rates calculated by the Census Bureau because DYNASIM3 includes the annuitized value of 80 percent of household assets in the income measure. The Census income measure includes only the return on capital (dividend, interest, and rental income). See the appendix for more details.
} 
Differential survival mutes the observed variation in retirement incomes at age 70. Table 9 shows survival rates by employment status. Among men age 45 to 54 in 2008, 85.5 percent of those who worked every year between 2008 and 2013 will survive to age 70, compared with only 73.6 percent of those with at least one year of zero earnings during that period - about a 12 percentage point difference. These results suggest that the impact of the recession would be even worse had these individuals survived to age 70 . Additionally, we would likely observe more significant effects for the recession if we compared retirement outcomes at younger ages, when more disadvantaged people would have been alive.

\section{Projected Outcomes Under Low-Wage-Growth Scenario}

Table 10 compares projected baseline outcomes at age 70 with projected outcomes under our low-wage-growth scenario. The low-wage-growth scenario assumes that wages would grow more slowly in the absence of the recession than under our no-recession scenario, with wage levels converging in 2023 in the baseline and low-wage-growth scenarios. Comparing this simulation with our baseline simulation shows the impact of the recession if it only affected employment rates between 2008 and 2023.

The results show that a recession that affects only short-term employment rates would not reduce retirement incomes much. Lifetime indexed earnings and economic well-being measures at age 70 (Social Security benefits, per capita household income, and poverty rates) are quite similar under the two scenarios. These results imply that most of the long-term effects of the recession result from slower wage growth, not from fewer years of employment. Unemployment affects relatively few workers (although the consequences can be severe for those who lose their jobs), whereas slow wage growth affects nearly all workers, and the impact can be significant when compounded over a lifetime.

\section{Conclusions}

Our projections show that the Great Recession, by many measures the most severe economic downturn since the Great Depression, will modestly reduce future retirement incomes. Workers unemployed for many months accumulated fewer Social Security and employer-sponsored pension credits and were less able to contribute to retirement accounts or save in other ways. 
Most workers, however, remained employed during the recession, and the reduction in work years for those who lost their jobs was generally inconsequential when averaged over entire careers. Even more important than the surge in unemployment during the recession was the interruption in wage growth. Wage stagnation will have serious long-term consequences if wages resume growing at their pre-recession rate since they will never make up the ground lost during the recession. Lower wage growth affects nearly all workers, not just the relatively few who lost their jobs. Our results show that average age-70 incomes for those age 25 to 64 when the recession began will fall 4.3 percent from the levels that would have prevailed had the recession not occurred, almost entirely because of the long-term reduction in wages.

The Social Security benefit formula partially protects benefits for those who lose their jobs. Social Security bases benefits on the average of the top 35 years of indexed earnings. Workers who spent more than 35 years in the labor force can replace an unemployment-spell year with one that includes full earnings, limiting unemployment's impact on the indexed earnings measure and future benefits. Social Security is also progressive, replacing a larger share of pre-retirement earnings for low-income workers than high-income workers. However, because the benefit formula indexes earnings at age 60 , wage growth before age 60 significantly affects future Social Security payments. Wage stagnation during the recession reduces the index factor in the benefit formula for everyone who turns 60 after 2008, effectively lowering the earnings counted by Social Security, even those received long before the recession began.

Because of the way Social Security indexes earnings, the Great Recession will reduce Social Security benefits for adults in their late fifties in 2008. Job losses will also limit later-life employment for those approaching retirement during the recession. Relatively few adults return to work after becoming unemployed in their early sixties. Combined, these two factors will reduce average age-70 income 4.1 percent for adults age 55 to 64 in 2008.

Average retirement incomes will decline more -4.9 percent—for adults who were in their late twenties and early thirties when unemployment rates began increasing in 2008. Unlike older adults, the impact of lower wages will accumulate over their entire careers. These younger workers were also more likely to lose their jobs during the recession.

Unemployment rates rose sharply during the recession for workers with limited education, yet the recession will not disproportionately reduce their retirement incomes. Higher- 
socioeconomic-status groups will experience the largest retirement income losses. In addition to limiting earnings and future Social Security benefits, reduced wages will lower pensions and retirement savings. These losses will not much affect low-income workers, because few have access to pensions or accumulate significant retirement savings even in good times. The most disadvantaged are also less likely to survive into old age. Low-income and less-educated workers have certainly suffered during the recession, with unemployment leaving many impoverished. And even modest retirement income losses could significantly reduce their economic well-being in later life, because their resources are so limited even in the absence of the recession. Nonetheless, it is noteworthy that retirement incomes will fall most sharply for well-educated, high-income workers, the same groups that bore the brunt of the stock market crash associated with the financial crisis (Butrica, Smith, and Toder 2009, 2010).

Projecting incomes over the next 40 years involves much uncertainty, and future developments could lead to outcomes very different from our forecasts. For example, the unusually long unemployment spells that characterized the Great Recession could seriously scar workers who lost their jobs and lead to worse outcomes than our model projects. Alternatively, average wages could bounce back to their pre-recession levels, offsetting much of the recessionary losses. The recession might also induce some workers to change their behavior to improve their retirement security. They might work more intensively when young, or save more. Although DYNASIM3 does not project much change in retirement timing, some workers might choose to delay retirement and work longer, increasing their lifetime earnings, Social Security credits, and ability to save while reducing the number of retirement years that their savings must finance. Butrica, Smith, and Steuerle (2007) found that working an additional year would boost average annual retirement incomes by 9 percent overall, and increase annual incomes among those in the bottom fifth of the income distribution by 16 percent.

Retirement projections are more certain for those who were in their late fifties when the recession began. The recession will undoubtedly reduce their Social Security income because the index factor in the benefit formula is lower today than it would have been had the recession not occurred. Moreover, those older workers who lost their jobs in the recession have limited employment prospects and little chance of extending their working lives. Unlike workers who were young when the recession hit and have years to adjust before retiring, there is little older 
workers can do to offset their recession-induced losses.

\section{Appendix}

This appendix provides additional information about how DYNASIM3 projects income. It describes our projections of income from pensions, retirement accounts, and other assets.

\section{Projecting Pensions}

DYNASIM3 projects pensions from employer-sponsored DB plans, CB plans, and retirement accounts. Starting information about pension coverage on current and past jobs, pension contribution rates, and account balances come from SIPP self-reported information. Projected DB pension information reflects pension plan structures through December 2008, including DB pension plan freezes and conversions to CB plans. Various data sources and models, as described below, are used to project job changes, pension coverage, pension participation, and pension contributions into the future.

DYNASIM3 projects DB pensions using the Pension Benefit Guaranty Corporation's (PBGC) Pension Insurance Modeling System (PIMS) DB plan formulas, which are randomly assigned to DB participants based on broad industry, union status, and firm size categories, and an indicator of whether the firm offers dual (DB and DC) coverage. DYNASIM3 uses actual benefit formulas to calculate benefits for federal government workers and military personnel, and uses tables of replacement rates from BLS to calculate replacement rates for state and local government workers. DYNASIM3 varies the probability of selecting a joint and survivor annuity by gender, education, family health status, wealth, and expected pension income. It also varies DB cost-of-living adjustments by employment sector (i.e., private, federal, state, and local). The model projects conversions of pension plan type (from DB to $\mathrm{CB}$ or DB to DC) using actual plan change information for plans included in the PIMS data.

Most DB plan formulas assign DB pension income as a function of plan earnings and job tenure. Most private pensions require five years of employment before workers are vested in the DB plan. Any shortening of job tenure directly reduces expected DB pension income. 


\section{Projecting Retirement Accounts}

DYNASIM3 starts with the self-reported SIPP retirement account balance. Because of documented deficiencies in the SIPP asset data (Czajka, Jacobson, and Cody 2003; Smith, Cashin, Favreault 2005), asset balances in retirement accounts (as well as financial assets outside of retirement accounts) in DYNASIM3's starting SIPP sample are adjusted to align with asset distributions from the 2007 Survey of Consumer Finances (SCF). Individuals are also assigned an individual-specific risk tolerance based on SCF data. An individual's share of retirement account assets invested in equities varies by age and risk tolerance, with high-risk and younger individuals investing more in equities than low-risk and older individuals.

DYNASIM3 uses historical price changes and returns for stocks, long-term corporate bonds, and long-term government bonds through 2008 to grow portfolios. Investment experience varies for each individual because the model sets rates of return stochastically, using historical means and standard deviations. We account for the 2008 stock market crash, which reduced equity values by 37 percent, by assuming that the market recovers to half of its projected precrash value by 2017 (Butrica, Smith, Toder 2010). Specifically, DYNASIM3 assumes a 10.7 percent average real rate of return on stocks from 2009 to 2017 before resuming to its historic average real return of 6.5 percent. DYNASIM3 assumes mean real rates of return of 3.5 percent for corporate bonds, 3.0 percent for government bonds, and standard deviations of 17.28 percent for stocks and 2.14 percent for bonds. ${ }^{6}$ The 6.5 percent real return on stocks reflects a capital appreciation of about 3.5 percent and a dividend yield of around 3.0 percent, in line with the long-term performance of the S\&P 500. The model subtracts one percentage point from annual stock and bond returns to reflect administrative costs.

DYNASIM3 allows some workers to cash out retirement account balances with job changes or job losses. Younger workers, workers with lower account balances, and workers who lose their jobs are more likely to cash out retirement account balances than are older workers, those with higher balances, and those who move seamlessly from one job to another. High

\footnotetext{
${ }^{6}$ The assumed rates of return are those recommended by the Social Security Administration's Office of the Chief Actuary for the President's Commission to Strengthen Social Security (2001). The standard deviations are derived from real returns over the 55-year period between 1952 and 2007 for large company stocks and Treasury bills reported in Ibbotson Associates (2008). Inflation assumptions follow the 2010 intermediate assumptions used by the Social Security trustees (Social Security Board of Trustees 2010).
} 
unemployment contributes to lower lifetime DC pension savings through loss of contributions (and returns on lost contributions) when out of work and hardship withdrawals.

\section{Projecting Financial Assets}

DYNASIM3 uses random-effects models developed for the Social Security Administration's MINT model to project financial assets. DYNASIM3 starts with SIPP self-reported assets (saving, checking, money market, CD, stocks, bonds, equity in businesses, vehicles, and nonhome real estate, less unsecured debt). Like retirement accounts, we adjust the SIPP starting values to align with the household asset distribution from the 2007 SCF. Unlike retirement accounts that are directly invested in stock and bond portfolios, financial assets accumulate and decumulate as a function of family characteristics and earnings and projected wage differentials. The main economic explanatory variable is the individual's lifetime earnings relative to the cohort average. Individuals with above-average lifetime earnings accumulate assets faster than those with below-average lifetime earnings. A spell of unemployment will lower a worker's average compared with one who remained employed continuously. The longer the unemployment spell, the greater is the differential in lifetime earnings relative to the cohort average and the impact on projected assets. Assets accumulate at the family level, so husbands and wives equally share family assets. We assume that couples split assets at divorce and survivors inherit the assets of deceased spouses.

DYNASIM3 projects nonpension financial assets over three separate age ranges: up to age 50, from age 51 to retirement, and from retirement to death. Equations projecting assets to age 50 were estimated on the Panel Study of Income Dynamics (Toder et al. 2002). Equations projecting assets from age 51 to retirement were estimated on the first seven waves of the Health and Retirement Study (HRS) (Smith et al. 2007). Equations projecting assets from retirement to death were estimated on a synthetic panel of SIPP data (Toder et al. 1999). The latter two data sets included historic earnings from the Social Security Administration's Summary Earnings Record (SER) data. 


\section{Asset Income}

DYNASIM3 measures income from retirement accounts and financial assets each year as the real (price-indexed), actuarially fair, annuity income a family would receive if it annuitized 80 percent of its total wealth. We use the calculated annuity value to assign only that year's income from retirement accounts and financial assets. The annuity factor is recalculated each year to reflect changes in wealth as individuals age, based on DYNASIM3 projections of wealth accumulation and spend-down and changes in life expectancy and marital status as individuals survive to older ages. For married couples, DYNASIM3 assumes a 50 percent survivor annuity.

We measure income from financial wealth and retirement accounts as potential annuities to ensure comparability with DB pension and Social Security benefits, which are also annuities. Without this adjustment, DYNASIM3 would overstate the loss in retirement wellbeing from the shift from DB pension income to DC assets. A dollar in DB pension wealth produces more income by standard measures than a dollar in DC wealth because measured DB income counts both a return on accumulated assets and some return of principal, while measured income from financial wealth and DC retirement accounts includes only the return on accumulated assets. The income measure we use therefore differs conceptually from asset income as measured by the United States Census Bureau (as well as many other analysts), which includes only the return on assets (interest, dividends, and rental income) and excludes the potential consumption of capital that could be realized if people spent down their wealth.

DYNASIM3 also projects income of non-spouse family members. We use this income primarily for determining poverty status, as these family member's incomes and characteristics are included in the standard poverty measure. We include spousal income in our measure of family income but exclude incomes of other family members in this report. 


\section{References}

Borie-Holtz, Debbie, Carl Van Horn, and Cliff Zukin. 2010. "No End in Sight: The Agony of Prolonged Unemployment.” New Brunswick, NJ: John J. Heldrich Center for Workforce Development, Rutgers University.

Bricker, Jesse, Brian Bucks, Arthur Kennickell, Traci Mach, and Kevin Moore. 2011. "Surveying the Aftermath of the Storm: Changes in Family Finances from 2007 to 2009." Finance and Economics Discussion Series 2011-17. Washington, D.C.: Board of Governors of the Federal Reserve Board.

Bureau of Economic Analysis. 2011. "National Income and Product Accounts Tables." Washington, DC: U.S. Department of Commerce. http://www.bea.gov/national/nipaweb/Index.asp.

Bureau of Labor Statistics. 2011a. "Employment, Hours, and Earnings from the Current Employment Statistics Survey." Washington, DC: U.S. Department of Labor. http://data.bls.gov/pdq/querytool.jsp? survey=ce.

- 2011b. "Labor Force Statistics from the Current Population Survey." Washington, DC: U.S. Department of Labor. http://data.bls.gov/pdq/querytool.jsp?survey=ln.

Butrica, Barbara A., Karen E. Smith, and Eugene Steuerle. 2007. "Working for a Good Retirement." In Government Spending on the Elderly, edited by Dimitri B. Papadimitriou (141-74). New York: Palgrave Macmillan.

Butrica, Barbara A., Karen E. Smith, and Eric J. Toder. 2009. "Retirement Security and the Stock Market Crash: What Are the Possible Outcomes?" Washington, DC: The Urban Institute.

- 2010. "What the 2008 Stock Market Crash Means for Retirement Security." Journal of Aging \& Social Policy 22(4): 339-59.

Butrica, Barbara A., Sheila R. Zedlewski, and Philip Issa. 2010. "Understanding Early Withdrawals from Retirement Accounts." Washington, DC: The Urban Institute.

Christelis, Dimitris, Dimitris Georgarakos, and Tullio Jappelli. 2011. "Wealth Shocks, Unemployment Shocks and Consumption in the Wake of the Great Recession." CSEF Working Paper No. 279. Naples, Italy: Centre for Studies in Economics and Finance, University of Naples.

Citro, Constance F., and Robert T. Michael. 1995. Measuring Poverty: A New Approach. Washington, DC: National Academy Press. 
Czajka, John L., Jonathan E. Jacobson, and Scott Cody. 2003. "Survey Estimates of Wealth: Comparative Analysis and Review of the Survey of Income and Program Participation." Washington, DC: Social Security Administration. http://www.ssa.gov/policy/docs/ssb/v65n1/v65n1p63.html.

DeNavas-Walt, Carmen, Bernadette D. Proctor, and Jessica C. Smith. 2010. "Income, Poverty, and Health Insurance Coverage in the United States: 2009." Current Population Reports P60-238. Washington, DC: United States Census Bureau.

Eberts, Randall W. 2011. "When Will U.S. Employment Recover from the Great Recession?" International Labor Brief 9(2): 4-12. http://research.upjohn.org/jrnlarticles/153.

Elsby, Michael W., Bart Hobijn, and Aysegul Sahin. 2010. "The Labor Market in the Great Recession.” NBER Working Paper 15979. Cambridge, MA: National Bureau of Economic Research.

Farber, Henry S. 2005. "What Do We Know about Job Loss in the United States? Evidence from the Displaced Workers Survey, 1984-2004." Industrial Relations Section Working Paper No. 498. Princeton, NJ: Princeton University.

Ferraira, Fernando, Joseph Gyourko, and Joseph Tracy. 2010. "Housing Busts and Household Mobility.” Journal of Urban Economics 69(1): 34-45.

Godofsky, Jessica, Carl Van Horn, and Cliff Zukin. 2010. “American Workers Assess an Economic Disaster." New Brunswick, NJ: John J. Heldrich Center for Workforce Development, Rutgers University.

Hurd, Michael D., and Susann Rohwedder. 2010. "Effects of the Financial Crisis and Great Recession on American Households.” NBER Working Paper 16407. Cambridge, MA: National Bureau of Economic Research.

Ibbotson Associates. 2008. "Stocks, Bonds, Bills, and Inflation (SBBI) 2008 Yearbook: Market Results for 1926-2007." Chicago: Ibbotson Associates.

Johnson, Richard W., and Janice S. Park. 2011a. "Can Older Unemployed Workers Find Work?" Older Americans' Economic Security No. 25. Washington, DC: The Urban Institute.

_. 2011b. "How did 50+ Workers Fare in 2010?" Retirement Security Data Brief No. 2. Washington, DC: The Urban Institute.

Mishel, Lawrence, and Heidi Shierholz. 2010. "Recession Hits Workers' Paychecks.” EPI Briefing Paper No. 277. Washington, DC: Economic Policy Institute. 
President's Commission to Strengthen Social Security. 2001. "Strengthening Social Security and Creating Personal Wealth for all Americans: Report of the President's Commission." Washington, DC: President's Commission to Strengthen Social Security.

Short, Kathleen S. 2010. "Who Is Poor? A New Look with the Supplemental Poverty Measure." SEHSD Working Paper 2010-15. Washington, DC: U.S. Census Bureau.

Smith, Karen E., Melissa Favreault, and David Cashin. 2005. "Modeling Income in the Near Term 4." Washington, DC: The Urban Institute.

Smith, Karen E., Melissa M. Favreault, Caroline Ratcliffe, Barbara Butrica, Eric Toder and Jon Bakija. 2007. "Modeling Income in the Near Term5." Washington, DC: The Urban Institute.

Social Security Board of Trustees. 2008. The 2008 Annual Report of the Board of Trustees of the Federal Old-Age and Survivors Insurance and Disability Insurance Trust Funds. Washington, DC: Board of Trustees.

- 2010. The 2010 Annual Report of the Board of Trustees of the Federal Old-Age and Survivors Insurance and Disability Insurance Trust Funds. Washington, DC: Board of Trustees.

Solon, Gary, Robert Barsky, and Jonathan A. Parker. 1994. "Measuring the Cyclicality of Real Wages: How Important Is Composition Bias?" Quarterly Journal of Economics 109(1): $1-25$.

Sullivan, James X. 2008. "Borrowing During Unemployment: Unsecured Debt as a Safety Net." Journal of Human Resources 43(2): 383-412.

Toder, Eric, Cori Uccello, John O’Hare, Melissa Favreault, Caroline Ratcliffe, Karen Smith, Gary Burtless, and Barry Bosworth. 1999. "Modeling Income in the Near TermProjections of Retirement Income through 2020 for the 1931-1960 Birth Cohorts." Washington, DC: The Urban Institute.

Toder, Eric, Larry Thompson, Melissa Favreault, Richard Johnson, Kevin Perese, Caroline Ratcliffe, Karen Smith, Cori Uccello, Timothy Waidmann, Jillian Berk, Romina Woldemariam, Gary Burtless, Claudia Sahm, and Douglas Wolf. 2002. "Modeling Income in the Near Term: Revised Projections of Retirement Income through 2020 for the 1931-1960 Birth Cohorts.” Washington, DC: The Urban Institute.

Vroman, Wayne (2010). "The Great Recession, Unemployment Insurance, and Poverty." Washington, DC: The Urban Institute. 

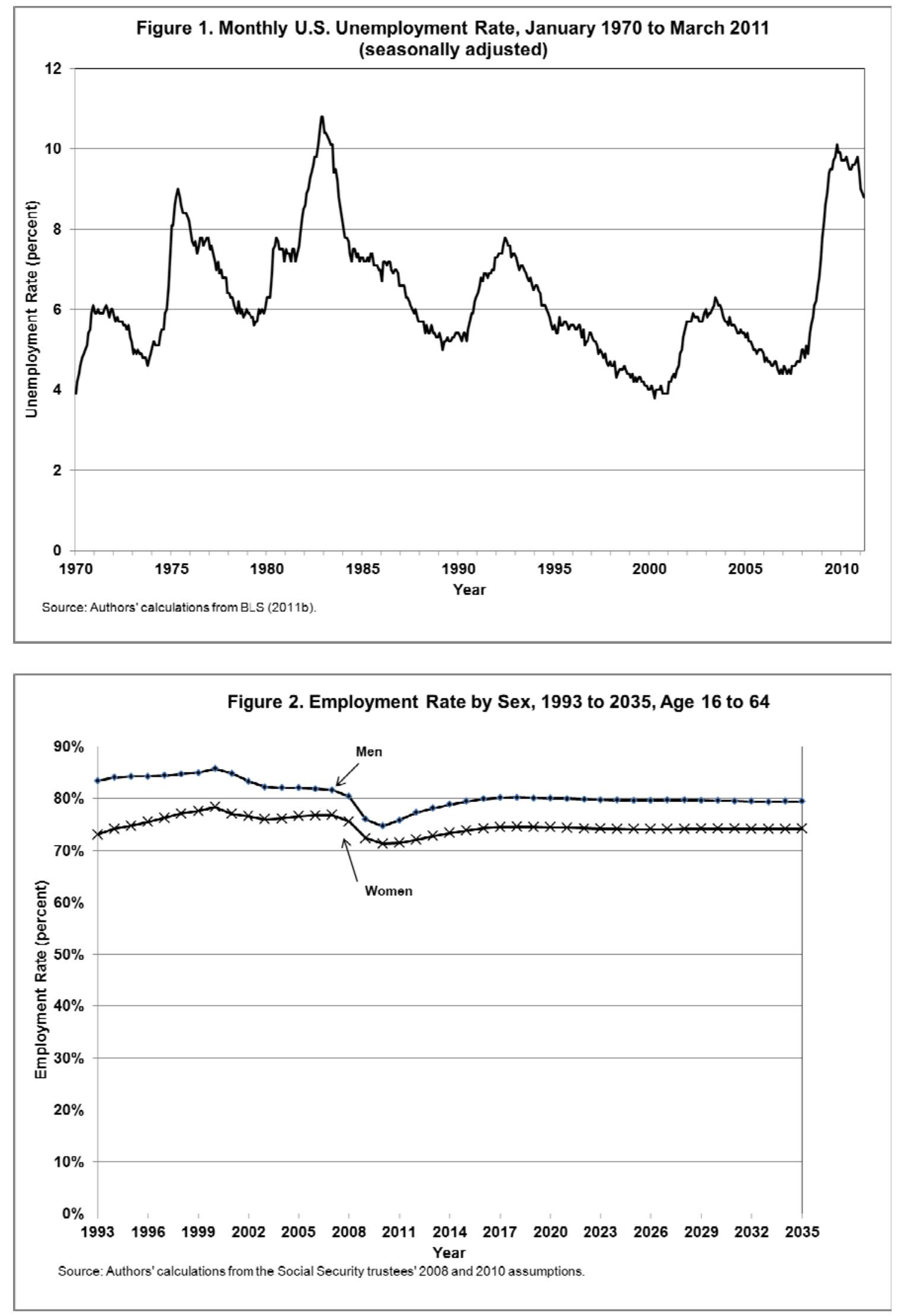

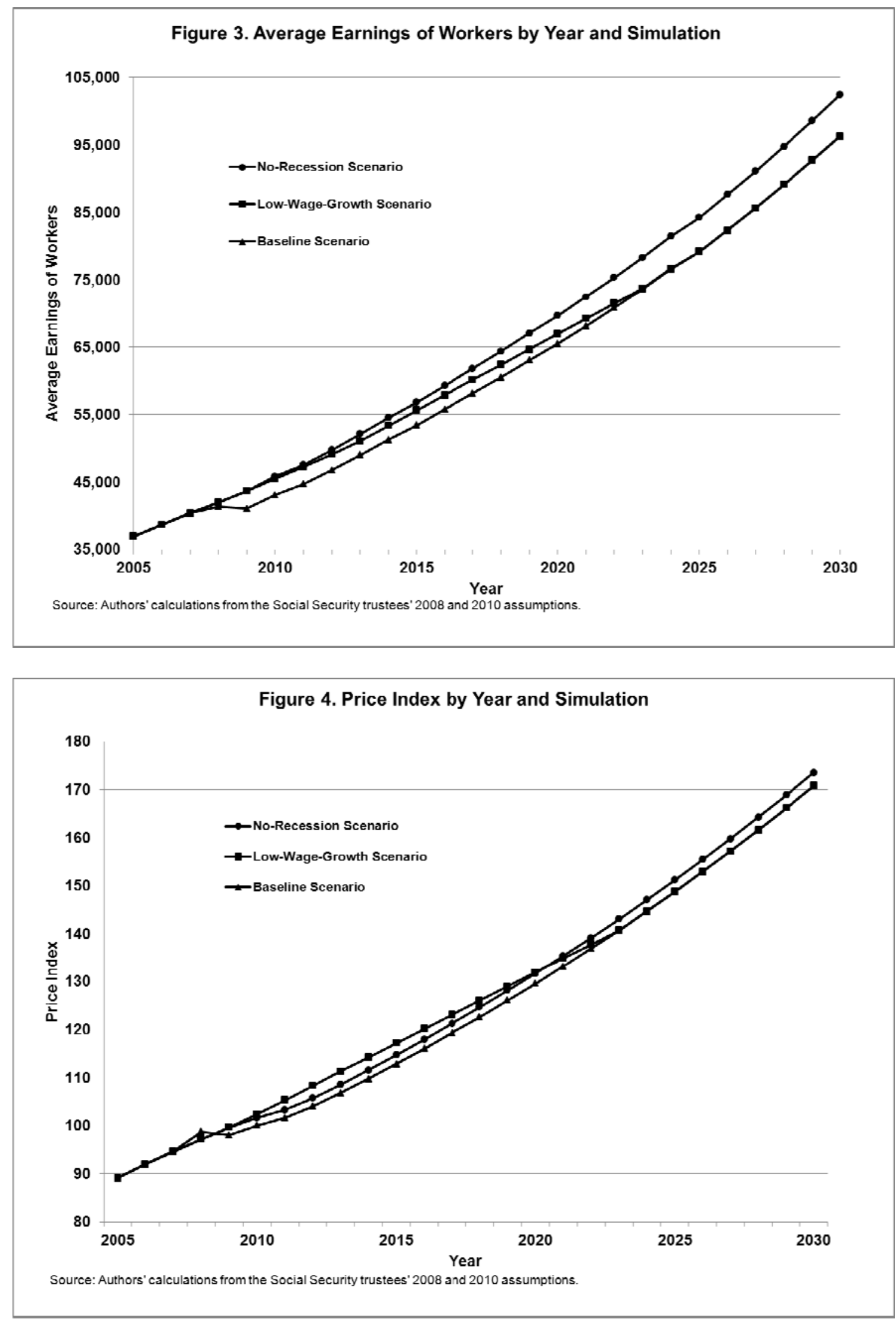
Table 1. Average Monthly Unemployment Rates by Sex, Education, Age, Race, and Hispanic Origin, 2010

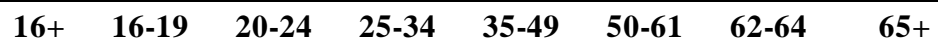

MEN

\begin{tabular}{|c|c|c|c|c|c|c|c|c|}
\hline All & 10.5 & 28.8 & 17.8 & 10.9 & 8.5 & 8.3 & 7.6 & 7.1 \\
\hline Not high school grad & 18.8 & 32.7 & 27.0 & 17.0 & 14.7 & 14.2 & 13.8 & 10.0 \\
\hline High school grad & 13.2 & 28.7 & 22.2 & 14.4 & 10.8 & 10.1 & 8.7 & 7.7 \\
\hline Some college & 9.9 & 18.4 & 13.2 & 10.9 & 8.5 & 8.2 & 8.8 & 7.9 \\
\hline 4 or more years of college & 5.0 & na & 10.8 & 4.7 & 4.3 & 5.2 & 5.2 & 5.5 \\
\hline Non-Hispanic white & 8.9 & 24.6 & 15.3 & 9.3 & 7.2 & 7.3 & 6.9 & 6.4 \\
\hline Not high school grad & 20.4 & 27.9 & 32.1 & 21.7 & 16.0 & 14.3 & 7.3 & 7.8 \\
\hline High school grad & 11.5 & 24.4 & 19.6 & 12.9 & 9.6 & 9.3 & 8.8 & 6.2 \\
\hline Some college & 8.8 & 15.6 & 11.4 & 9.8 & 7.5 & 7.6 & 9.0 & 8.4 \\
\hline 4 or more years of college & 4.5 & na & 9.4 & 4.3 & 3.7 & 4.6 & 4.9 & 5.2 \\
\hline African American & 18.4 & 44.5 & 29.6 & 19.5 & 14.8 & 13.4 & 12.3 & 10.6 \\
\hline Not high school grad & 33.0 & 49.5 & 50.2 & 36.9 & 27.0 & 19.6 & 16.1 & 10.1 \\
\hline High school grad & 21.1 & 45.5 & 31.8 & 23.9 & 17.2 & 15.1 & 13.0 & 13.7 \\
\hline Some college & 15.0 & 27.5 & 21.2 & 16.5 & 12.5 & 12.4 & 14.5 & 8.5 \\
\hline 4 or more years of college & 9.9 & na & 23.8 & 9.1 & 9.7 & 8.7 & 7.5 & 8.4 \\
\hline Hispanic & 12.7 & 34.6 & 18.2 & 11.6 & 10.2 & 10.8 & 12.0 & 9.4 \\
\hline Not high school grad & 14.7 & 39.6 & 17.5 & 12.5 & 12.3 & 12.7 & 20.3 & 12.3 \\
\hline High school grad & 14.0 & 32.4 & 21.7 & 13.2 & 10.9 & 11.7 & 3.5 & 12.4 \\
\hline Some college & 11.0 & 25.1 & 15.2 & 10.0 & 9.5 & 9.1 & 4.8 & 1.9 \\
\hline 4 or more years of college & 6.0 & na & 12.9 & 6.4 & 4.4 & 6.9 & 11.1 & 6.2 \\
\hline \multicolumn{9}{|l|}{ WOMEN } \\
\hline All & 8.6 & 22.8 & 13.0 & 9.1 & 7.4 & 6.5 & 5.7 & 6.2 \\
\hline Not high school grad & 18.6 & 27.5 & 30.1 & 20.0 & 15.5 & 10.8 & 7.9 & 7.2 \\
\hline High school grad & 10.4 & 23.5 & 17.8 & 12.4 & 9.0 & 7.7 & 5.3 & 6.5 \\
\hline Some college & 8.3 & 14.2 & 10.0 & 9.8 & 7.6 & 6.5 & 6.2 & 7.2 \\
\hline 4 or more years of college & 4.9 & na & 7.9 & 5.1 & 4.5 & 4.5 & 5.0 & 4.6 \\
\hline Non-Hispanic white & 7.0 & 18.2 & 10.0 & 7.0 & 6.2 & 5.6 & 5.6 & 5.7 \\
\hline Not high school grad & 17.3 & 21.6 & 26.3 & 22.5 & 15.1 & 8.4 & 8.3 & 4.6 \\
\hline High school grad & 8.8 & 19.3 & 15.1 & 10.3 & 8.1 & 6.9 & 5.2 & 6.0 \\
\hline Some college & 7.0 & 11.6 & 8.0 & 8.2 & 6.3 & 5.7 & 6.4 & 6.9 \\
\hline 4 or more years of college & 4.2 & na & 6.6 & 3.8 & 4.0 & 4.1 & 5.1 & 4.5 \\
\hline African American & 13.8 & 40.5 & 22.6 & 16.2 & 10.6 & 8.6 & 5.2 & 8.0 \\
\hline Not high school grad & 28.0 & 47.6 & 47.8 & 28.5 & 23.8 & 11.0 & 6.6 & 12.5 \\
\hline High school grad & 15.6 & 37.7 & 25.0 & 18.9 & 12.4 & 10.1 & 7.4 & 7.7 \\
\hline Some college & 12.6 & 28.7 & 17.7 & 16.5 & 9.7 & 8.7 & 4.0 & 8.8 \\
\hline 4 or more years of college & 7.4 & na & 14.6 & 9.4 & 6.4 & 5.9 & 3.0 & 4.7 \\
\hline Hispanic & 12.3 & 29.1 & 16.2 & 10.9 & 10.7 & 10.7 & 7.2 & 9.6 \\
\hline Not high school grad & 17.2 & 37.2 & 25.5 & 16.2 & 14.6 & 13.2 & 8.4 & 9.9 \\
\hline High school grad & 12.8 & 28.0 & 18.0 & 12.1 & 10.7 & 10.3 & 5.1 & 10.4 \\
\hline Some college & 10.6 & 16.0 & 12.0 & 8.8 & 10.6 & 11.0 & 5.7 & 11.5 \\
\hline 4 or more years of college & 6.8 & na & 12.7 & 6.9 & 5.5 & 6.8 & 9.3 & 5.1 \\
\hline
\end{tabular}

Source: Authors' computations from the monthly files of the 2010 Current Population Survey.

Note: The table reports the average of the monthly unemployment rate from January through December,

2010. The unemployment rate is the share of the civilian labor force that is out of work and looking for work. 
Table 2. Average Monthly Underemployment Rates by Sex, Education, Age, Race, and Hispanic Origin, 2010

\begin{tabular}{|c|c|c|c|c|c|c|c|c|}
\hline & $16+$ & $16-19$ & $20-24$ & $25-34$ & $35-49$ & $50-61$ & $62-64$ & $65+$ \\
\hline \multicolumn{9}{|l|}{ MEN } \\
\hline All & 16.0 & 40.0 & 29.0 & 16.6 & 12.6 & 12.3 & 12.5 & 11.3 \\
\hline Not high school grad & 28.3 & 41.3 & 42.5 & 27.6 & 23.1 & 22.1 & 21.3 & 16.3 \\
\hline High school grad & 19.7 & 44.9 & 34.5 & 21.5 & 15.7 & 14.6 & 14.4 & 11.7 \\
\hline Some college & 15.2 & 28.2 & 23.2 & 16.2 & 12.2 & 12.5 & 13.9 & 12.6 \\
\hline 4 or more years of college & 7.7 & na & 18.0 & 7.5 & 6.3 & 7.6 & 9.1 & 9.1 \\
\hline Non-Hispanic white & 13.5 & 35.2 & 25.5 & 14.0 & 10.2 & 10.9 & 11.2 & 10.1 \\
\hline Not high school grad & 28.7 & 35.5 & 47.5 & 32.1 & 22.6 & 21.5 & 17.1 & 12.3 \\
\hline High school grad & 17.2 & 40.8 & 31.0 & 19.4 & 13.6 & 13.4 & 13.8 & 9.8 \\
\hline Some college & 13.6 & 24.9 & 21.0 & 14.3 & 10.7 & 11.7 & 13.5 & 12.6 \\
\hline 4 or more years of college & 6.9 & na & 16.5 & 6.8 & 5.4 & 6.9 & 8.2 & 8.6 \\
\hline African American & 25.8 & 57.8 & 43.4 & 26.8 & 20.6 & 18.2 & 19.6 & 17.7 \\
\hline Not high school grad & 44.7 & 60.6 & 67.3 & 47.5 & 39.9 & 28.3 & 26.6 & 18.6 \\
\hline High school grad & 29.3 & 64.1 & 47.5 & 31.4 & 23.8 & 20.4 & 20.9 & 17.6 \\
\hline Some college & 21.6 & 35.7 & 32.3 & 24.2 & 17.6 & 16.4 & 18.6 & 19.0 \\
\hline 4 or more years of college & 13.5 & na & 31.2 & 13.2 & 12.5 & 11.4 & 14.7 & 15.8 \\
\hline Hispanic & 20.6 & 46.6 & 30.6 & 19.6 & 16.8 & 17.4 & 19.5 & 16.0 \\
\hline Not high school grad & 24.5 & 49.8 & 31.9 & 23.1 & 20.9 & 21.3 & 25.4 & 21.5 \\
\hline High school grad & 22.2 & 47.0 & 33.9 & 21.3 & 17.4 & 17.7 & 15.4 & 20.6 \\
\hline Some college & 17.8 & 37.3 & 26.1 & 16.1 & 14.5 & 15.2 & 14.8 & 5.8 \\
\hline 4 or more years of college & 10.0 & na & 22.6 & 10.3 & 8.1 & 11.0 & 15.5 & 7.7 \\
\hline \multicolumn{9}{|l|}{ WOMEN } \\
\hline All & 15.6 & 33.6 & 25.4 & 16.1 & 13.7 & 12.1 & 10.3 & 11.2 \\
\hline Not high school grad & 30.8 & 35.3 & 47.8 & 35.0 & 29.2 & 22.7 & 16.7 & 13.8 \\
\hline High school grad & 19.1 & 40.7 & 33.6 & 22.5 & 16.8 & 14.0 & 10.0 & 11.5 \\
\hline Some college & 15.5 & 23.8 & 21.2 & 17.1 & 14.0 & 12.3 & 11.2 & 12.7 \\
\hline 4 or more years of college & 8.8 & na & 16.9 & 8.8 & 7.9 & 8.2 & 8.4 & 8.7 \\
\hline Non-Hispanic white & 13.1 & 28.1 & 21.7 & 13.0 & 11.6 & 10.5 & 9.6 & 10.3 \\
\hline Not high school grad & 26.9 & 28.1 & 45.7 & 36.6 & 27.5 & 16.4 & 12.9 & 9.5 \\
\hline High school grad & 16.7 & 36.6 & 30.6 & 20.1 & 15.2 & 12.6 & 9.7 & 10.7 \\
\hline Some college & 13.6 & 20.5 & 18.5 & 14.8 & 12.4 & 11.3 & 10.6 & 12.1 \\
\hline 4 or more years of college & 8.0 & na & 15.4 & 7.5 & 7.3 & 7.7 & 8.3 & 8.4 \\
\hline African American & 21.7 & 51.6 & 37.3 & 24.5 & 17.0 & 14.8 & 11.8 & 13.1 \\
\hline Not high school grad & 40.8 & 57.5 & 61.0 & 43.4 & 36.8 & 27.2 & 13.3 & 17.2 \\
\hline High school grad & 24.9 & 51.6 & 42.4 & 29.0 & 20.1 & 16.8 & 11.8 & 12.9 \\
\hline Some college & 20.7 & 39.0 & 31.7 & 25.0 & 16.3 & 14.2 & 13.1 & 15.3 \\
\hline 4 or more years of college & 11.2 & na & 24.7 & 13.5 & 9.3 & 9.1 & 8.0 & 8.3 \\
\hline Hispanic & 22.9 & 43.1 & 29.8 & 20.5 & 21.0 & 21.1 & 16.7 & 17.4 \\
\hline Not high school grad & 32.2 & 48.7 & 43.7 & 32.1 & 29.8 & 27.5 & 23.1 & 20.3 \\
\hline High school grad & 24.5 & 47.3 & 33.1 & 23.3 & 21.5 & 21.1 & 11.3 & 16.8 \\
\hline Some college & 19.5 & 27.8 & 23.3 & 16.8 & 18.8 & 19.2 & 16.0 & 19.4 \\
\hline 4 or more years of college & 11.8 & na & 23.7 & 10.6 & 10.5 & 12.2 & 13.4 & 10.8 \\
\hline
\end{tabular}

Source: Authors' computations from the monthly files of the 2010 Current Population Survey.

Note: The table reports the average of the monthly underemployment rate from January through December, 2010. The underemployment rate is the share of the civilian labor force that is out of work and looking for work, working part-time because they cannot find full-time employment, and those who stopped looking for work because they became discouraged. 


\begin{tabular}{|c|c|c|c|c|c|c|c|c|c|c|c|c|c|c|c|}
\hline \multirow[b]{2}{*}{ Age in 2008} & \multicolumn{5}{|c|}{ Employment Rate (\%) } & \multicolumn{5}{|c|}{ Absolute Change Due to Recession } & \multicolumn{5}{|c|}{ Percent Change Due to Recession } \\
\hline & \multicolumn{2}{|r|}{$25-34$} & $35-44$ & $45-54$ & $55-64$ & \multicolumn{2}{|r|}{$25-34$} & \multirow{2}{*}{$\begin{array}{c}35-44 \\
2034-43 \\
\end{array}$} & \multirow{2}{*}{\begin{tabular}{|c|}
$45-54$ \\
$2024-33$ \\
\end{tabular}} & \multirow{2}{*}{$\begin{array}{c}55-64 \\
2014-23 \\
\end{array}$} & \multicolumn{2}{|c|}{$25-34$} & \multirow{2}{*}{$\begin{array}{c}35-44 \\
2034-43\end{array}$} & \multirow{2}{*}{$\begin{array}{c}45-54 \\
2024-33 \\
\end{array}$} & \multirow{2}{*}{$\begin{array}{c}55-64 \\
2014-23 \\
\end{array}$} \\
\hline Year Age 70 & All & 2044-53 & 2034-43 & 2024-33 & 2014-23 & All & $2044-53$ & & & & All & 2044-53 & & & \\
\hline All & 71.1 & 74.1 & 73.8 & 74.7 & 59.8 & $-3.4 * * *$ & $-3.7 * * *$ & $-3.9 * * *$ & $-3.3 * * *$ & $-2.5 * * *$ & -4.6 & -4.8 & -5.0 & -4.2 & -4.0 \\
\hline \multicolumn{16}{|l|}{ Gender } \\
\hline Female & 67.8 & 70.7 & 71.2 & 72.6 & 54.5 & $-2.5 * * *$ & $-2.9 * * *$ & $-3.0 * * *$ & $-1.9 * * *$ & $-2.1 * *$ & -3.6 & -3.9 & -4.0 & -2.6 & -3.7 \\
\hline Male & 74.8 & 77.8 & 76.4 & 77.0 & 65.9 & $-4.4 * * *$ & $-4.4 * * *$ & $-4.9 * * *$ & $-4.9 * * *$ & $-3.0 * * *$ & -5.6 & -5.4 & -6.0 & -6.0 & -4.4 \\
\hline \multicolumn{16}{|l|}{ Race/Ethnicity } \\
\hline Non-Hispanic white & 75.3 & 79.8 & 78.1 & 78.8 & 63.6 & $-3.3 * * *$ & $-3.8 * * *$ & $-3.9 * * *$ & $-3.1 * * *$ & $-2.4 * * *$ & -4.2 & -4.5 & -4.8 & -3.8 & -3.6 \\
\hline Non-Hispanic black & 67.2 & 78.0 & 73.9 & 68.5 & 38.3 & $-4.0 * * *$ & $-2.9 * *$ & $-4.4 * * *$ & $-4.7 * * *$ & $-4.1 *$ & -5.6 & -3.6 & -5.6 & -6.4 & -9.7 \\
\hline Hispanic & 58.2 & 60.3 & 59.0 & 58.1 & 51.5 & $-3.9 * * *$ & $-4.3 * * *$ & $-4.4 * * *$ & $-4.2 * *$ & -1.6 & -6.3 & -6.7 & -6.9 & -6.7 & -3.0 \\
\hline Asian/Native American & 62.6 & 59.8 & 64.3 & 67.6 & 59.0 & $-2.4 * *$ & -2.5 & -2.2 & -2.3 & -2.8 & -3.7 & -4.0 & -3.3 & -3.3 & -4.5 \\
\hline \multicolumn{16}{|l|}{ Education } \\
\hline Did not complete high school & 38.9 & 42.6 & 40.4 & 38.7 & 33.3 & $-4.2 * * *$ & $-5.2 * * *$ & $-4.7 * * *$ & $-4.8 * * *$ & -1.5 & -9.7 & -10.9 & -10.4 & -11.0 & -4.3 \\
\hline High school graduate or some college & 71.1 & 75.4 & 74.1 & 75.5 & 57.3 & $-3.7 * * *$ & $-3.9 * * *$ & $-4.3 * * *$ & $-3.7 * * *$ & $-2.8 * * *$ & -4.9 & -4.9 & -5.5 & -4.7 & -4.7 \\
\hline College graduate & 83.1 & 82.4 & 84.9 & 87.7 & 75.8 & $-2.5 * * *$ & $-2.9 * * *$ & $-2.8 * * *$ & $-1.8 * *$ & $-2.4 * *$ & -2.9 & -3.4 & -3.2 & -2.0 & -3.1 \\
\hline \multicolumn{16}{|l|}{ Years Worked from Age 15 through } \\
\hline \multicolumn{16}{|l|}{2010} \\
\hline$<=10$ & 35.0 & 44.9 & 29.2 & 22.6 & 18.9 & $-3.0 * * *$ & $-3.9 * * *$ & $-2.5 * *$ & -2.3 & -0.8 & -7.9 & -8.0 & -7.9 & -9.2 & -4.1 \\
\hline $11-29$ & 77.2 & 89.1 & 81.5 & 63.4 & 36.8 & $-3.7^{* * *}$ & $-3.2 * * *$ & $-4.0 * * *$ & $-4.5 * * *$ & $-2.4 *$ & -4.6 & -3.5 & -4.7 & -6.6 & -6.1 \\
\hline $30+$ & 81.6 & 0.0 & 96.5 & 90.3 & 71.1 & $-2.6 * * *$ & 0.0 & $-2.4 * * *$ & $-2.6 * * *$ & $-2.7 * * *$ & -3.1 & . & -2.4 & -2.8 & -3.7 \\
\hline \multicolumn{16}{|l|}{ Own Lifetime Earnings Quintile 2010} \\
\hline Bottom & 29.9 & 28.7 & 31.2 & 33.2 & 25.5 & $-2.7 * * *$ & $-2.9 * *$ & $-3.1 * *$ & $-3.2 * *$ & -1.4 & -8.3 & -9.2 & -9.0 & -8.8 & -5.2 \\
\hline Second & 69.3 & 75.7 & 72.2 & 74.3 & 51.9 & $-4.5 * * *$ & $-5.4 * * *$ & $-5.6 * * *$ & $-3.5 * * *$ & $-2.9 * *$ & -6.1 & -6.7 & -7.2 & -4.5 & -5.3 \\
\hline Third & 79.7 & 84.3 & 83.1 & 83.1 & 65.8 & $-3.7^{* * *}$ & $-3.8 * * *$ & $-4.3^{* * *}$ & $-4.0 * * *$ & -2.0 & -4.4 & -4.3 & -4.9 & -4.6 & -2.9 \\
\hline Fourth & 86.1 & 89.5 & 89.9 & 89.4 & 73.3 & $-3.2 * * *$ & $-3.0 * * *$ & $-3.0 * * *$ & $-3.2 * * *$ & $-3.5 * * *$ & -3.6 & -3.2 & -3.2 & -3.5 & -4.6 \\
\hline Top & 90.6 & 92.5 & 92.6 & 93.4 & 82.4 & $-3.0 * * *$ & $-3.1^{* * *}$ & $-3.4 * * *$ & $-2.7 * * *$ & $-2.8 * * *$ & -3.2 & -3.2 & -3.5 & -2.8 & -3.3 \\
\hline
\end{tabular}

Source: DYNASIM3 projections.

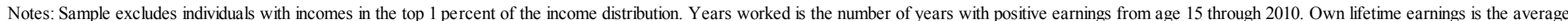
of price-indexed earnings from age 15 until 2010. Quintiles are calculated within age groups.

*** significant at $1 \%$ level, ** significant at $5 \%$ level, * significant at $10 \%$ level. 
Table 4. Projected Work Histories of Future Retirees at Age 70

\begin{tabular}{|c|c|c|c|c|c|c|c|c|c|c|c|c|c|c|c|}
\hline \multirow[b]{2}{*}{ Age in 2008} & \multicolumn{5}{|c|}{ Baseline Work History } & \multicolumn{5}{|c|}{ Absolute Change Due to Recession } & \multicolumn{5}{|c|}{ Percent Change Due to Recession } \\
\hline & \multicolumn{2}{|r|}{$25-34$} & $35-44$ & $45-54$ & $55-64$ & \multicolumn{2}{|r|}{$25-34$} & \multirow{2}{*}{\begin{tabular}{|c|}
$35-44$ \\
$2034-43$
\end{tabular}} & \multirow{2}{*}{\begin{tabular}{|c|}
$45-54$ \\
$2024-33$
\end{tabular}} & \multirow{2}{*}{$\begin{array}{c}55-64 \\
2014-23\end{array}$} & \multicolumn{2}{|r|}{$25-34$} & \multirow{2}{*}{$\begin{array}{c}35-44 \\
2034-43\end{array}$} & \multirow{2}{*}{\begin{tabular}{|c|}
$45-54$ \\
$2024-33$
\end{tabular}} & \multirow{2}{*}{\begin{tabular}{|c|}
$55-64$ \\
$2014-23$ \\
\end{tabular}} \\
\hline Year Age 70 & All & 2044-53 & 2034-43 & 2024-33 & 2014-23 & All & 2044-53 & & & & All & 2044-53 & & & \\
\hline Average Years Worked & 31.1 & 31.1 & 31.2 & 31.2 & 30.8 & -0.1 & -0.1 & -0.2 & -0.2 & -0.1 & -0.3 & -0.3 & -0.6 & -0.6 & -0.3 \\
\hline \multicolumn{16}{|c|}{ Distribution of Years Worked (\%) } \\
\hline$<=10$ & 8 & 7 & 8 & 8 & 9 & 0.1 & 0.1 & 0.0 & 0.2 & 0.1 & 1.2 & 1.4 & 0.0 & 2.5 & 1.1 \\
\hline $11-29$ & 24 & 27 & 23 & 22 & 22 & 0.3 & 0.4 & 0.6 & 0.4 & 0.0 & 1.3 & 1.5 & 2.7 & 1.8 & 0.0 \\
\hline $30+$ & 68 & 66 & 69 & 69 & 68 & $-0.5 *$ & -0.5 & -0.6 & -0.5 & -0.1 & -0.7 & -0.7 & -0.9 & -0.7 & -0.1 \\
\hline
\end{tabular}

Source: DYNASIM3 projections.

Notes: Sample excludes individuals with incomes in the top 1 percent of the income distribution. Years worked is the number of years with positive earnings from age 22 to 62.

*** significant at $1 \%$ level, ** significant at $5 \%$ level, * significant at $10 \%$ level.

Table 5. Projected Income of Future Retirees at Age 70

\begin{tabular}{|c|c|c|c|c|c|c|c|c|c|c|c|c|c|c|c|}
\hline \multirow[b]{2}{*}{ Age in 2008} & \multicolumn{5}{|c|}{ Avergage Income (thousaands of 2007 \$) } & \multicolumn{5}{|c|}{ Absolute Change Due to Recession (thousaands of 2007 \$) } & \multicolumn{5}{|c|}{ Percent Change Due to Recession } \\
\hline & & $25-34$ & $35-44$ & $45-54$ & $55-64$ & & $25-34$ & $35-44$ & $45-54$ & $55-64$ & & $25-34$ & $35-44$ & $45-54$ & $55-64$ \\
\hline Year Age 70 & All & 2044-53 & 2034-43 & 2024-33 & 2014-23 & All & 2044-53 & $2034-43$ & 2024-33 & 2014-23 & All & 2044-53 & 2034-43 & 2024-33 & 2014-23 \\
\hline Own Lifetime Earnings & 34.6 & 39.9 & 37.4 & 31.1 & 28.9 & $-1.2 * * *$ & $-2.0 * * *$ & $-1.7^{* * *}$ & $-0.7 * *$ & -0.2 & -3.4 & -4.8 & -4.3 & -2.2 & -0.7 \\
\hline Shared Lifetime Earnings & 34.1 & 39.5 & 36.6 & 30.9 & 28.6 & $-1.2 * * *$ & $-2.0 * * *$ & $-1.6^{* * *}$ & $-0.7 * * *$ & -0.2 & -3.4 & -4.8 & -4.2 & -2.2 & -0.7 \\
\hline Own Social Security Benefits & 16.2 & 18.5 & 17.0 & 15.3 & 13.7 & $-0.7^{* * *}$ & $-0.9 * * *$ & $-0.8 * * *$ & $-0.6 * * *$ & $-0.2 * * *$ & -4.1 & -4.6 & -4.5 & -3.8 & -1.4 \\
\hline Per Capita Household Social Security Benefits & 15.2 & 17.3 & 15.8 & 14.4 & 12.9 & $-0.6 * * *$ & $-0.7 * * *$ & $-0.7 * * *$ & $-0.6 * * *$ & $-0.2 * * *$ & -3.8 & -3.9 & -4.2 & -4.0 & -1.5 \\
\hline
\end{tabular}

Source: DYNASIM3 projections.

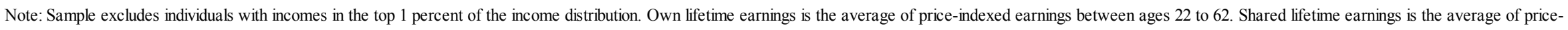
indexed shared earnings between ages 22 and 62, where shared earnings are half the total earnings of the couple in the years when married and individual earnings in years when not married.

*** significant at $1 \%$ level, ${ }^{* *}$ significant at $5 \%$ level, * significant at $10 \%$ level. 


\begin{tabular}{|c|c|c|c|c|c|c|c|c|c|c|c|c|c|c|c|}
\hline \multirow[b]{2}{*}{ Age in 2008} & \multicolumn{5}{|c|}{$\begin{array}{l}\text { Average Per Capita Household Income } \\
\text { (thousands of \$2007) }\end{array}$} & \multicolumn{5}{|c|}{ Absolute Change Due to Recession } & \multicolumn{5}{|c|}{ Percent Change Due to Recession } \\
\hline & \multicolumn{2}{|c|}{$25-34$} & $35-44$ & $45-54$ & $55-64$ & \multicolumn{2}{|r|}{$25-34$} & $35-44$ & \multirow{2}{*}{$\begin{array}{c}45-54 \\
2024-33\end{array}$} & \multirow{2}{*}{\begin{tabular}{|c|}
$55-64$ \\
$2014-23$ \\
\end{tabular}} & \multicolumn{2}{|c|}{$25-34$} & $35-44$ & $45-54$ & \multirow{2}{*}{$\begin{aligned} 55-64 \\
2014-23\end{aligned}$} \\
\hline Year Age 70 & All & 2044-53 & 2034-43 & 2024-33 & 2014-23 & All & 2044-53 & 2034-43 & & & All & 2044-53 & 2034-43 & 2024-33 & \\
\hline \multicolumn{16}{|l|}{ All } \\
\hline Total Income & 51.6 & 57.8 & 54.7 & 46.7 & 46.4 & $-2.3 * * *$ & $-3.0 * * *$ & $-2.3 * * *$ & $-2.0 * * *$ & $-2.0 * * *$ & -4.3 & -4.9 & -4.0 & -4.1 & -4.1 \\
\hline Earnings & 10.9 & 12.6 & 12.1 & 9.5 & 9.1 & $-0.6 * * *$ & $-0.6 * *$ & -0.2 & $-0.6 * *$ & $-0.9 * * *$ & -5.2 & -4.5 & -1.6 & -5.9 & -9.0 \\
\hline DB Pension Benefits & 4.0 & 3.7 & 3.5 & 3.7 & 5.5 & $-0.2 * *$ & $-0.3 *$ & -0.2 & -0.2 & 0.0 & -4.8 & -7.5 & -5.4 & -5.1 & 0.0 \\
\hline DC Assets & 5.8 & 6.4 & 6.4 & 5.5 & 4.7 & $-0.2 * * *$ & $-0.5 * * *$ & $-0.3 * *$ & -0.1 & -0.1 & -3.3 & -7.2 & -4.5 & -1.8 & -2.1 \\
\hline Social Security Benefits & 15.2 & 17.3 & 15.8 & 14.4 & 12.9 & $-0.6 * * *$ & $-0.7 * * *$ & $-0.7 * * *$ & $-0.6 * * *$ & $-0.2 * * *$ & -3.8 & -3.9 & -4.2 & -4.0 & -1.5 \\
\hline SSI Benefits & 0.1 & 0.1 & 0.1 & 0.1 & 0.2 & $0.0 * *$ & 0.0 & 0.0 & 0.0 & 0.0 & 0.0 & 0.0 & 0.0 & 0.0 & 0.0 \\
\hline Non-Pension Assets & 15.6 & 17.8 & 16.8 & 13.4 & 14.1 & $-0.7 * * *$ & $-0.8 *$ & $-0.8 * *$ & $-0.6 *$ & $-0.7 *$ & -4.3 & -4.3 & -4.5 & -4.3 & -4.7 \\
\hline \multicolumn{16}{|l|}{ Bottom Quintile } \\
\hline Total Income & 9.8 & 10.9 & 9.8 & 9.5 & 9.0 & $-0.4 * * *$ & $-0.4 * * *$ & $-0.4 * * *$ & $-0.3 * * *$ & -0.1 & -3.9 & -3.5 & -3.9 & -3.1 & -1.1 \\
\hline Earnings & 0.6 & 0.7 & 0.6 & 0.5 & 0.6 & 0.0 & 0.0 & 0.0 & 0.0 & 0.0 & 0.0 & 0.0 & 0.0 & 0.0 & 0.0 \\
\hline DB Pension Benefits & 0.3 & 0.3 & 0.3 & 0.3 & 0.3 & 0.0 & $0.0 *$ & 0.1 & 0.0 & 0.0 & 0.0 & 0.0 & 50.0 & 0.0 & 0.0 \\
\hline DC Assets & 0.3 & 0.4 & 0.4 & 0.3 & 0.3 & 0.0 & $0.0 * *$ & 0.1 & 0.0 & 0.0 & 0.0 & 0.0 & 33.3 & 0.0 & 0.0 \\
\hline Social Security Benefits & 7.0 & 7.9 & 6.9 & 6.8 & 6.2 & $-0.3 * * *$ & $-0.3 * *$ & $-0.3 * *$ & $-0.3 * * *$ & -0.1 & -4.1 & -3.7 & -4.2 & -4.2 & -1.6 \\
\hline SSI Benefits & 0.6 & 0.5 & 0.6 & 0.6 & 0.8 & $0.0 * *$ & 0.1 & 0.0 & 0.0 & 0.1 & 0.0 & 25.0 & 0.0 & 0.0 & 14.3 \\
\hline Non-Pension Assets & 1.0 & 1.2 & 1.1 & 1.0 & 0.8 & $-0.1 * * *$ & 0.0 & $-0.1 * *$ & $-0.1 * *$ & 0.0 & -9.1 & 0.0 & -8.3 & -9.1 & 0.0 \\
\hline \multicolumn{16}{|l|}{ Middle Quintile } \\
\hline Total Income & 34.8 & 37.7 & 36.1 & 32.8 & 32.1 & $-1.7 * * *$ & $-2.1 * * *$ & $-2.0 * * *$ & $-1.4 * * *$ & $-1.2 * * *$ & -4.7 & -5.3 & -5.2 & -4.1 & -3.6 \\
\hline Earnings & 6.0 & 6.7 & 6.5 & 5.4 & 5.3 & $-0.4 * * *$ & $-0.4 *$ & -0.3 & $-0.4 *$ & $-0.6 * * *$ & -6.3 & -5.6 & -4.4 & -6.9 & -10.2 \\
\hline DB Pension Benefits & 2.6 & 2.1 & 2.1 & 2.4 & 3.8 & $-0.1 * * *$ & -0.1 & -0.2 & $-0.2 *$ & -0.2 & -3.7 & -4.5 & -8.7 & -7.7 & -5.0 \\
\hline DC Assets & 4.1 & 4.1 & 4.3 & 4.0 & 3.8 & $-0.2 * * *$ & $-0.3 *$ & $-0.4 * * *$ & -0.1 & -0.1 & -4.7 & -6.8 & -8.5 & -2.4 & -2.6 \\
\hline Social Security Benefits & 16.4 & 18.4 & 17.2 & 15.6 & 14.0 & $-0.5 * * *$ & $-0.9 * * *$ & $-0.6 * * *$ & $-0.5 * * *$ & -0.1 & -3.0 & -4.7 & -3.4 & -3.1 & -0.7 \\
\hline SSI Benefits & 0.0 & 0.0 & 0.0 & 0.0 & 0.0 & 0.0 & 0.0 & 0.0 & 0.0 & 0.0 & 0.0 & 0.0 & 0.0 & 0.0 & 0.0 \\
\hline Non-Pension Assets & 5.7 & 6.3 & 6.0 & 5.3 & 5.2 & $-0.4 * * *$ & $-0.5 * *$ & $-0.6 * * *$ & -0.2 & $-0.2 *$ & -6.6 & -7.4 & -9.1 & -3.6 & -3.7 \\
\hline \multicolumn{16}{|l|}{ Top Quintile } \\
\hline Total Income & 134.3 & 153.5 & 144.7 & 117.6 & 119.0 & $-5.9 * * *$ & $-7.5 * * *$ & $-5.0 * * *$ & $-5.2 * * *$ & $-5.8 * * *$ & -4.2 & -4.7 & -3.3 & -4.2 & -4.6 \\
\hline Earnings & 31.8 & 37.7 & 35.5 & 27.2 & 25.6 & $-1.2 * * *$ & -1.5 & 0.3 & $-1.5 *$ & $-2.6 * * *$ & -3.6 & -3.8 & 0.9 & -5.2 & -9.2 \\
\hline DB Pension Benefits & 11.0 & 10.5 & 9.9 & 10.0 & 14.4 & $-0.7 * *$ & -1.1 & -0.9 & -0.3 & 0.0 & -6.0 & -9.5 & -8.3 & -2.9 & 0.0 \\
\hline DC Assets & 15.5 & 18.0 & 17.5 & 14.1 & 11.8 & $-0.5 *$ & -0.9 & -0.4 & -0.3 & -0.3 & -3.1 & -4.8 & -2.2 & -2.1 & -2.5 \\
\hline Social Security Benefits & 20.8 & 24.1 & 21.8 & 19.5 & 17.1 & $-0.9 * * *$ & $-0.9 * * *$ & $-1.1 * * *$ & $-0.9 * * *$ & $-0.5 * * *$ & -4.1 & -3.6 & -4.8 & -4.4 & -2.8 \\
\hline SSI Benefits & 0.0 & 0.0 & 0.0 & 0.0 & 0.0 & 0.0 & 0.0 & 0.0 & 0.0 & 0.0 & 0.0 & 0.0 & 0.0 & 0.0 & 0.0 \\
\hline Non-Pension Assets & 55.3 & 63.3 & 60.0 & 46.8 & 50.1 & $-2.5 * * *$ & -2.8 & $-2.8 *$ & $-2.1 *$ & -2.4 & -4.3 & -4.2 & -4.5 & -4.3 & -4.6 \\
\hline
\end{tabular}

Source: DYNASIM3 projections.

Notes: Sample excludes individuals with incomes in the top 1 percent of the income distribution. Quintiles are calculated within age groups. The sum of the components of income does not always equal total income because of rounding.

*** significant at $1 \%$ level, ${ }^{* *}$ significant at $5 \%$ level, * significant at $10 \%$ level. 
Table 7. Projected Number and Share of Adults with Low Incomes at Age 70

\begin{tabular}{|c|c|c|c|c|c|c|c|c|c|c|c|c|c|c|c|}
\hline \multirow[b]{2}{*}{ Age in 2008} & \multicolumn{5}{|c|}{ Baseline Simulation } & \multicolumn{5}{|c|}{ Absolute Change Due to Recession } & \multicolumn{5}{|c|}{ Percent Change Due to Recession } \\
\hline & & $25-34$ & $35-44$ & $45-54$ & 55-64 & & $25-34$ & $35-44$ & $45-54$ & $55-64$ & & $25-34$ & $35-44$ & $45-54$ & $55-64$ \\
\hline Year Age 70 & All & 2044-53 & 2034-43 & 2024-33 & 2014-23 & All & 2044-53 & 2034-43 & 2024-33 & 2014-23 & All & 2044-53 & $2034-43$ & 2024-33 & 2014-23 \\
\hline Percent with Income Below $100 \%$ of FPL & 4.9 & 3.9 & 5.0 & 5.4 & 5.5 & 0.2 & 0.1 & 0.3 & 0.3 & 0.2 & 4.3 & 2.6 & 6.4 & 5.9 & 3.8 \\
\hline Percent with Income Below 125\% of FPL & 7.3 & 5.7 & 7.1 & 7.9 & 8.6 & $0.5 * * *$ & $0.5 *$ & $0.5 *$ & $0.5^{*}$ & 0.5 & 7.4 & 9.6 & 7.6 & 6.8 & 6.2 \\
\hline $\begin{array}{l}\text { Number with Income Below } 100 \% \text { of FPL } \\
\text { (thousands) }\end{array}$ & 6,971 & 1,444 & 1,863 & 2,039 & 1,663 & 284.5 & 37.0 & 111.8 & 113.3 & 60.5 & 4.3 & 2.6 & 6.4 & 5.9 & 3.8 \\
\hline $\begin{array}{l}\text { Number with Income Below 125\% of FPL } \\
\text { (thousands) }\end{array}$ & 10,385 & 2,111 & 2,645 & 2,982 & 2,600 & $711.3^{* * *}$ & $185.2 *$ & $186.3 *$ & $188.8 *$ & 151.1 & 7.4 & 9.6 & 7.6 & 6.8 & 6.2 \\
\hline
\end{tabular}

Source: DYNASIM3 projections.

Note: Sample excludes individuals with incomes in the top 1 percent of the income distribution. FPL= federal poverty level.

*** significant at $1 \%$ level, $* *$ significant at $5 \%$ level, * significant at $10 \%$ level. 


\begin{tabular}{|c|c|c|c|c|c|c|c|c|c|c|c|c|c|c|c|}
\hline \multirow[b]{2}{*}{ Age in 2008} & \multicolumn{5}{|c|}{$\begin{array}{l}\text { Average Per Capita Household Income } \\
\text { (thousands of \$2007) }\end{array}$} & \multicolumn{5}{|c|}{ Absolute Change Due to Recession (thousands of \$2007) } & \multicolumn{5}{|c|}{ Percent Change Due to Recession } \\
\hline & \multirow{2}{*}{\multicolumn{2}{|c|}{$\begin{array}{c}25-34 \\
2044-53\end{array}$}} & $35-44$ & $45-54$ & $55-64$ & \multicolumn{2}{|r|}{$25-34$} & \multirow{2}{*}{$\begin{array}{c}35-44 \\
2034-43\end{array}$} & \multirow{2}{*}{\begin{tabular}{|c|}
$45-54$ \\
$2024-33$
\end{tabular}} & \multirow{2}{*}{$\begin{array}{c}55-64 \\
2014-23\end{array}$} & \multicolumn{2}{|r|}{ 25-34 } & \multirow{2}{*}{$35-44$} & \multirow{2}{*}{\begin{tabular}{|c|}
$45-54$ \\
$32024-33$ \\
\end{tabular}} & \multirow{2}{*}{\begin{tabular}{|c|}
$55-64$ \\
$2014-23$
\end{tabular}} \\
\hline Year Age 70 & & & 2034-43 & 2024-33 & 2014-23 & All & 2044-53 & & & & All & 2044-53 & & & \\
\hline All & 51.6 & 57.8 & 54.7 & 46.7 & 46.4 & $-2.3 * * *$ & $-3.0 * * *$ & $-2.3 * * *$ & $-2.0 * * *$ & $-2.0 * * *$ & -4.3 & -4.9 & -4.0 & -4.1 & -4.1 \\
\hline \multicolumn{16}{|l|}{ Gender } \\
\hline Female & 49.0 & 55.3 & 51.7 & 44.9 & 43.6 & $-2.4 * * *$ & $-3.0 * * *$ & $-2.4 * * *$ & $-1.8 * *$ & $-2.2 * * *$ & -4.7 & -5.1 & -4.4 & -3.9 & -4.8 \\
\hline Male & 54.4 & 60.5 & 57.8 & 48.7 & 49.7 & $-2.3 * * *$ & $-2.9 * * *$ & $-2.1 * *$ & $-2.2 * * *$ & $-1.8 * *$ & -4.1 & -4.6 & -3.5 & -4.3 & -3.5 \\
\hline \multicolumn{16}{|l|}{ Race/Ethnicity } \\
\hline Non-Hispanic white & 59.1 & 68.2 & 63.7 & 53.1 & 52.7 & $-2.5 * * *$ & $-3.4 * * *$ & $-2.3 * * *$ & $-2.1 * * *$ & $-2.1 * * *$ & -4.1 & -4.7 & -3.5 & -3.8 & -3.8 \\
\hline Non-Hispanic black & 32.9 & 39.2 & 35.4 & 28.4 & 25.3 & $-1.5 * *$ & -1.5 & -1.7 & -1.5 & -1.2 & -4.4 & -3.7 & -4.6 & -5.0 & -4.5 \\
\hline Hispanic & 33.0 & 41.2 & 32.3 & 26.7 & 24.3 & $-2.2 * * *$ & $-2.3 *$ & $-2.6 * *$ & -1.4 & -1.5 & -6.3 & -5.3 & -7.4 & -5.0 & -5.8 \\
\hline Asian/Native American & 44.3 & 49.4 & 47.9 & 40.2 & 34.7 & $-2.7 * *$ & $-3.6 *$ & -2.3 & -1.6 & -2.7 & -5.7 & -6.8 & -4.6 & -3.8 & -7.2 \\
\hline \multicolumn{16}{|l|}{ Education } \\
\hline Did not complete high school & 21.7 & 26.2 & 22.8 & 19.4 & 17.7 & $-0.9 *$ & -1.1 & -1.1 & -0.9 & -0.5 & -4.0 & -4.0 & -4.6 & -4.4 & -2.7 \\
\hline High school graduate/some college & 42.5 & 48.9 & 44.4 & 38.8 & 38.2 & $-1.9 * * *$ & $-2.4 * * *$ & $-1.8 * *$ & $-1.6 * * *$ & $-1.8 * * *$ & -4.3 & -4.7 & -3.9 & -4.0 & -4.5 \\
\hline College graduate & 78.2 & 80.6 & 81.6 & 74.2 & 74.3 & $-3.4 * * *$ & $-4.3 * * *$ & $-3.1 * *$ & $-3.1 * *$ & $-3.1 * *$ & -4.2 & -5.1 & -3.7 & -4.0 & -4.0 \\
\hline \multicolumn{16}{|l|}{ Years Worked } \\
\hline$<=10$ & 18.0 & 19.6 & 17.9 & 17.5 & 17.1 & $-0.9 *$ & -1.1 & -1.4 & -0.5 & -0.7 & -4.8 & -5.3 & -7.3 & -2.8 & -3.9 \\
\hline $11-29$ & 33.5 & 39.0 & 33.4 & 29.4 & 30.8 & $-1.5 * * *$ & -1.6 & -1.3 & $-1.6 * *$ & -1.2 & -4.3 & -3.9 & -3.7 & -5.2 & -3.8 \\
\hline $30+$ & 62.0 & 69.5 & 66.4 & 55.8 & 55.5 & $-2.5 * * *$ & $-3.4 * * *$ & $-2.3 * * *$ & $-2.0 * * *$ & $-2.4 * * *$ & -3.9 & -4.7 & -3.3 & -3.5 & -4.1 \\
\hline Social Security Benefit Status & & & & & & & & & & & & & & & \\
\hline Retired, spouse, or survivor & 56.6 & 63.0 & 60.2 & 51.5 & 50.8 & $-2.5 * * *$ & $-3.3 * * *$ & $-2.5 * * *$ & $-1.9 * * *$ & $-2.1 * * *$ & -4.2 & -5.0 & -4.0 & -3.6 & -4.0 \\
\hline Disabled beneficiary & 36.9 & 42.9 & 40.2 & 32.1 & 31.0 & $-1.5 * *$ & -1.6 & -1.3 & $-1.8 *$ & -0.6 & -3.9 & -3.6 & -3.1 & -5.3 & -1.9 \\
\hline SSI & 6.7 & 6.5 & 6.3 & 6.8 & 7.1 & 0.0 & 0.1 & -0.1 & 0.1 & 0.0 & 0.0 & 1.6 & -1.6 & 1.5 & 0.0 \\
\hline Not beneficiary & 23.3 & 18.9 & 19.5 & 24.2 & 31.2 & -0.7 & -1.0 & 0.2 & -0.6 & -1.6 & -2.9 & -5.0 & 1.0 & -2.4 & -4.9 \\
\hline Own Lifetime Eamings Quintile & & & & & & & & & & & & & & & \\
\hline Bottom & 23.1 & 26.4 & 22.5 & 22.5 & 20.8 & $-1.2 * * *$ & -1.1 & $-1.5 *$ & $-1.4 *$ & -0.7 & -4.9 & -4.0 & -6.3 & -5.9 & -3.3 \\
\hline Second & 32.6 & 37.3 & 32.6 & 29.3 & 30.9 & $-1.7 * * *$ & $-2.3 * *$ & $-1.6 *$ & $-1.3 *$ & $-1.6 *$ & -5.0 & -5.8 & -4.7 & -4.2 & -4.9 \\
\hline Third & 43.3 & 48.9 & 45.5 & 39.3 & 39.0 & $-2.0 * * *$ & $-2.2 *$ & $-1.9 *$ & $-1.6 * *$ & $-1.9 * *$ & -4.4 & -4.3 & -4.0 & -3.9 & -4.6 \\
\hline Fourth & 60.2 & 64.7 & 66.6 & 53.9 & 54.6 & $-2.8 * * *$ & $-4.2 * * *$ & -2.1 & $-2.5 * *$ & $-2.2 *$ & -4.4 & -6.1 & -3.1 & -4.4 & -3.9 \\
\hline Top & 98.9 & 111.9 & 106.2 & 88.6 & 86.7 & $-4.0 * * *$ & $-4.9 * *$ & $-4.3 * *$ & $-3.2 * *$ & $-3.7 * *$ & -3.9 & -4.2 & -3.9 & -3.5 & -4.1 \\
\hline Shared Lifetime Eamings Quintile & & & & & & & & & & & & & & & \\
\hline Bottom & 16.0 & 18.7 & 15.7 & 14.5 & 15.0 & $-0.6 * *$ & -0.2 & $-0.8 *$ & -0.6 & -0.5 & -3.6 & -1.1 & -4.8 & -4.0 & -3.2 \\
\hline Second & 29.6 & 33.4 & 29.7 & 27.0 & 28.2 & $-1.7 * * *$ & $-2.4 * * *$ & $-1.9 * * *$ & $-1.2 * *$ & -1.2 & -5.4 & -6.7 & -6.0 & -4.3 & -4.1 \\
\hline Third & 43.3 & 46.6 & 45.4 & 40.1 & 40.6 & $-1.5 * * *$ & -1.5 & -1.4 & $-1.4 *$ & $-1.8 *$ & -3.3 & -3.1 & -3.0 & -3.4 & -4.2 \\
\hline Fourth & 60.9 & 65.2 & 65.6 & 56.9 & 54.7 & $-3.5 * * *$ & $-5.7 * * *$ & $-2.9 * *$ & $-2.5 * *$ & $-2.8 * *$ & -5.4 & -8.0 & -4.2 & -4.2 & -4.9 \\
\hline Top & 108.4 & 125.3 & 117.1 & 95.1 & 93.5 & $-4.3 * * *$ & $-4.9 * *$ & $-4.3 * *$ & $-4.2 * * *$ & $-3.9 * *$ & -3.8 & -3.8 & -3.5 & -4.2 & -4.0 \\
\hline Household Income Quintile & & & & & & & & & & & & & & & \\
\hline Bottom & 9.8 & 10.9 & 9.8 & 9.5 & 9.0 & $-0.4 * * *$ & $-0.4 * * *$ & $-0.4 * * *$ & $-0.3 * * *$ & -0.1 & -3.9 & -3.5 & -3.9 & -3.1 & -1.1 \\
\hline Second & 21.3 & 23.4 & 21.9 & 20.2 & 19.4 & $-1.0 * * *$ & $-1.4 * * *$ & $-1.2 * * *$ & $-0.8 * * *$ & $-0.6 * * *$ & -4.5 & -5.6 & -5.2 & -3.8 & -3.0 \\
\hline Third & 34.8 & 37.7 & 36.1 & 32.8 & 32.1 & $-1.7 * * *$ & $-2.1 * * *$ & $-2.0 * * *$ & $-1.4 * * *$ & $-1.2 * * *$ & -4.7 & -5.3 & -5.2 & -4.1 & -3.6 \\
\hline Fourth & 57.9 & 63.6 & 60.9 & 53.6 & 52.5 & $-2.7 * * *$ & $-3.4 * * *$ & $-2.9 * * *$ & $-2.2 * * *$ & $-2.5 * * *$ & -4.5 & -5.1 & -4.5 & -3.9 & -4.5 \\
\hline Top & 134.3 & 153.5 & 144.7 & 117.6 & 119.0 & $-5.9 * * *$ & $-7.5 * * *$ & $-5.0 * * *$ & $-5.2 * * *$ & $-5.8 * * *$ & -4.2 & -4.7 & -3.3 & -4.2 & -4.6 \\
\hline
\end{tabular}

Source: DYNASIM3 projections.

Note: Sample excludes individuals with incomes in the top 1 percent of the income distribution. Own lifetime earnings is the average of price-indexed earnings between ages 22 to 62 . Shared lifetime earnings is the average of price-indexed shared earnings between ages 22 and 62, where shared earnings are half the total earnings of the couple in the years when married and individual earnings in years when not married. Quintiles are

calculated within age groups. 
Table 9. Survival Rates at Age 70 by Employment Status from 2008 to 2013, Education, and Sex

\begin{tabular}{|c|c|c|c|c|c|c|}
\hline \multirow[b]{2}{*}{ Age in 2008} & \multicolumn{3}{|c|}{ Female } & \multicolumn{3}{|c|}{ Male } \\
\hline & \begin{tabular}{|c} 
Employed \\
Each Year \\
$(\%)$ \\
\end{tabular} & $\begin{array}{c}\text { Not } \\
\text { Employed at } \\
\text { Least One } \\
\text { Year (\%) } \\
\end{array}$ & $\begin{array}{c}\text { Absolute } \\
\text { Difference }\end{array}$ & $\begin{array}{c}\text { Employed } \\
\text { Each Year } \\
(\%) \\
\end{array}$ & $\begin{array}{c}\text { Not } \\
\text { Employed at } \\
\text { Least One } \\
\text { Year (\%) } \\
\end{array}$ & $\begin{array}{c}\text { Absolute } \\
\text { Difference }\end{array}$ \\
\hline \multicolumn{7}{|l|}{$25-34$} \\
\hline All & 86.7 & 83.2 & $-3.5 * * *$ & 82.0 & 77.5 & $-4.5 * * *$ \\
\hline Did not complete high school & 77.2 & 81.2 & 4.0 & 70.2 & 72.0 & 1.8 \\
\hline High school graduate/some college & 83.6 & 81.7 & -1.9 & 80.1 & 75.8 & $-4.3 * * *$ \\
\hline College graduate & 90.2 & 87.7 & $-2.5 * *$ & 86.6 & 86.1 & -0.5 \\
\hline \multicolumn{7}{|l|}{$35-44$} \\
\hline All & 86.1 & 82.8 & $-3.3 * * *$ & 83.2 & 75.8 & $-7.4 * * *$ \\
\hline Did not complete high school & 77.9 & 80.2 & 2.3 & 70.2 & 69.8 & -0.4 \\
\hline High school graduate/some college & 83.6 & 82.3 & -1.3 & 81.3 & 75.6 & $-5.7 * * *$ \\
\hline College graduate & 89.8 & 86.4 & $-3.4 * * *$ & 86.6 & 82.0 & $-4.6 * * *$ \\
\hline \multicolumn{7}{|l|}{$45-54$} \\
\hline All & 88.2 & 81.9 & $-6.3 * * *$ & 85.5 & 73.6 & $-11.9 * * *$ \\
\hline Did not complete high school & 78.4 & 80.4 & 2.0 & 79.1 & 69.1 & $-10.0 * * *$ \\
\hline High school graduate/some college & 86.6 & 81.6 & $-5.0 * * *$ & 83.4 & 73.5 & $-9.9 * * *$ \\
\hline College graduate & 91.5 & 85.4 & $-6.1 * * *$ & 89.1 & 78.9 & $-10.2 * * *$ \\
\hline \multicolumn{7}{|l|}{$55-64$} \\
\hline All & 93.8 & 87.1 & $-6.7 * * *$ & 91.0 & 80.3 & $-10.7 * * *$ \\
\hline Did not complete high school & 89.6 & 85.8 & -3.8 & 83.6 & 77.4 & $-6.2 *$ \\
\hline High school graduate/some college & 93.1 & 87.1 & $-6.0 * * *$ & 90.0 & 79.3 & $-10.7 * * *$ \\
\hline College graduate & 95.3 & 88.4 & $-6.9 * * *$ & 93.2 & 83.8 & $-9.4 * * *$ \\
\hline
\end{tabular}

Source: DYNASIM3 projections.

Note: Table includes all individuals age 25 to 64 living in the U.S. in 2008. The "employed each year" catergory includes individuals with postive earnings in all years between 2008 and 2013. The other category includes all individuals with no earnings in at least one year between 2008 and 2013. The survival rate is the share of the 2008 population that survives to age 70 .

*** significant at $1 \%$ level, $* *$ significant at $5 \%$ level, * significant at $10 \%$ level. 
Table 10. Impact of Recession on Projected Economic Well-Being of Future Retirees at Age 70, Assuming Wages Grew Slowly if the Recession Did Not Occur

\begin{tabular}{|c|c|c|c|c|c|c|c|c|c|c|}
\hline & \multicolumn{5}{|c|}{ Absolute Change Due to Recession } & \multicolumn{5}{|c|}{ Percent Change Due to Recession } \\
\hline Age in 2008 & & $25-34$ & $35-44$ & $45-54$ & $55-64$ & & 25-34 & $35-44$ & $45-54$ & $55-64$ \\
\hline Year Age 70 & All & 2044-53 & 2034-43 & 2024-33 & 2014-23 & All & 2044-53 & 2034-43 & 2024-33 & 2014-23 \\
\hline Average Years Worked & -0.1 & -0.1 & -0.2 & -0.2 & -0.1 & -0.3 & -0.3 & -0.6 & -0.6 & -0.3 \\
\hline \multicolumn{11}{|l|}{ Average Income (thousands of 2007 \$) } \\
\hline Own Lifetime Earnings & $-0.4 * *$ & -0.5 & -0.7 & -0.3 & -0.2 & -1.1 & -1.2 & -1.8 & -1.0 & -0.7 \\
\hline Shared Lifetime Earnings & $-0.5 * * *$ & -0.6 & $-0.6 *$ & -0.3 & -0.2 & -1.4 & -1.5 & -1.6 & -1.0 & -0.7 \\
\hline Own Social Security Benefits & $-0.2 * * *$ & 0.0 & 0.0 & $-0.4 * * *$ & $-0.1 *$ & -1.2 & 0.0 & 0.0 & -2.5 & -0.7 \\
\hline Per Capita Household Social Security Benefits & $-0.1 * * *$ & 0.1 & 0.0 & $-0.4 * * *$ & -0.1 & -0.7 & 0.6 & 0.0 & -2.7 & -0.8 \\
\hline Per Capita Household Income & $-0.6 *$ & -0.4 & -0.2 & -0.7 & -0.8 & -1.1 & -0.7 & -0.4 & -1.5 & -1.7 \\
\hline \multicolumn{11}{|l|}{ Income Relative to Federal Poverty Level (FPL) } \\
\hline Percent with Income Below 100\% of FPL & 0.0 & -0.1 & 0.0 & 0.1 & 0.1 & 0.0 & -2.5 & 0.0 & 1.9 & 1.9 \\
\hline Percent with Income Below 125\% of FPL & 0.2 & 0.2 & 0.1 & 0.3 & 0.2 & 2.8 & 3.6 & 1.4 & 3.9 & 2.4 \\
\hline Income to Poverty Ratio & -0.1 & 0.0 & 0.0 & -0.1 & -0.1 & -1.4 & 0.0 & 0.0 & -1.5 & -1.5 \\
\hline
\end{tabular}

\section{Source: DYNASIM3 projections.}

Note: This tables compares the baseline and low-wage-growth simulations. The low-wage-growth scenario assumes that wages would grow more slowly in the absence of the recession than under our no-recession scenario, with wage levels converging in 2023 in the baseline and low-wage-growth scenarios. The sample excludes individuals with incomes in the top 1 percent of the income distribution. Years worked is the number of years with positive earnings from age 22 to 62 . Own lifetime earnings is the average of price-indexed earnings between ages 22 to 62 . Shared lifetime earnings is the average of price-indexed shared earnings between ages 22 and 62 , where shared earnings are half the total earnings of the couple in the years when married and individual earnings in years when not married.

*** significant at $1 \%$ level, ** significant at $5 \%$ level, * significant at $10 \%$ level. 
Appendix Table 1. Male Employment Rates by Age and Year

\begin{tabular}{|c|c|c|c|c|c|c|c|c|c|c|c|c|c|c|c|c|}
\hline & \multicolumn{16}{|c|}{ Age } \\
\hline & 15 & 16 to 17 & 18 to 19 & 20 to 24 & 25 to 49 & 50 to 54 & 55 to 59 & 60 to 61 & 62 & 63 to 64 & 65 to 66 & 67 to 69 & $70-74$ & $75-79$ & 80-84 & 26-64 \\
\hline & \multicolumn{16}{|c|}{ Baseline Employment Rates } \\
\hline Year & & & & & & & & & & & & & & & & \\
\hline 2007 & 0.183 & 0.406 & 0.751 & 0.839 & 0.867 & 0.862 & 0.788 & 0.725 & 0.668 & 0.577 & 0.489 & 0.381 & 0.295 & 0.164 & 0.104 & 0.816 \\
\hline 2008 & 0.188 & 0.358 & 0.698 & 0.808 & 0.858 & 0.857 & 0.801 & 0.727 & 0.653 & 0.576 & 0.540 & 0.409 & 0.293 & 0.167 & 0.100 & 0.804 \\
\hline 2009 & 0.170 & 0.311 & 0.590 & 0.754 & 0.815 & 0.823 & 0.760 & 0.720 & 0.680 & 0.556 & 0.524 & 0.409 & 0.285 & 0.178 & 0.093 & 0.760 \\
\hline 2010 & 0.165 & 0.273 & 0.540 & 0.748 & 0.807 & 0.810 & 0.748 & 0.700 & 0.652 & 0.532 & 0.541 & 0.403 & 0.283 & 0.172 & 0.104 & 0.747 \\
\hline 2011 & 0.165 & 0.284 & 0.551 & 0.755 & 0.826 & 0.811 & 0.749 & 0.696 & 0.643 & 0.537 & 0.533 & 0.411 & 0.288 & 0.165 & 0.104 & 0.758 \\
\hline 2012 & 0.165 & 0.299 & 0.577 & 0.767 & 0.843 & 0.819 & 0.757 & 0.706 & 0.655 & 0.544 & 0.535 & 0.423 & 0.297 & 0.172 & 0.104 & 0.773 \\
\hline 2013 & 0.170 & 0.315 & 0.606 & 0.781 & 0.848 & 0.827 & 0.768 & 0.710 & 0.651 & 0.546 & 0.569 & 0.453 & 0.308 & 0.179 & 0.104 & 0.781 \\
\hline 2014 & 0.170 & 0.330 & 0.632 & 0.794 & 0.853 & 0.836 & 0.778 & 0.719 & 0.660 & 0.551 & 0.576 & 0.470 & 0.319 & 0.186 & 0.104 & 0.789 \\
\hline 2015 & 0.170 & 0.342 & 0.654 & 0.804 & 0.856 & 0.845 & 0.785 & 0.724 & 0.663 & 0.553 & 0.568 & 0.468 & 0.328 & 0.192 & 0.105 & 0.794 \\
\hline 2016 & 0.170 & 0.352 & 0.672 & 0.810 & 0.858 & 0.851 & 0.793 & 0.730 & 0.667 & 0.559 & 0.577 & 0.483 & 0.333 & 0.190 & 0.105 & 0.799 \\
\hline 2017 & 0.161 & 0.360 & 0.684 & 0.813 & 0.859 & 0.854 & 0.798 & 0.736 & 0.674 & 0.557 & 0.556 & 0.458 & 0.341 & 0.199 & 0.105 & 0.801 \\
\hline 2018 & 0.170 & 0.361 & 0.689 & 0.813 & 0.860 & 0.855 & 0.800 & 0.739 & 0.677 & 0.551 & 0.553 & 0.454 & 0.347 & 0.208 & 0.105 & 0.802 \\
\hline 2019 & 0.182 & 0.359 & 0.693 & 0.812 & 0.859 & 0.852 & 0.802 & 0.741 & 0.679 & 0.549 & 0.561 & 0.464 & 0.350 & 0.217 & 0.105 & 0.801 \\
\hline 2020 & 0.191 & 0.359 & 0.694 & 0.811 & 0.858 & 0.847 & 0.807 & 0.745 & 0.683 & 0.550 & 0.556 & 0.457 & 0.351 & 0.219 & 0.105 & 0.800 \\
\hline 2021 & 0.183 & 0.359 & 0.690 & 0.811 & 0.857 & 0.844 & 0.808 & 0.748 & 0.687 & 0.551 & 0.549 & 0.454 & 0.350 & 0.218 & 0.105 & 0.799 \\
\hline 2022 & 0.173 & 0.358 & 0.689 & 0.812 & 0.855 & 0.845 & 0.807 & 0.749 & 0.692 & 0.554 & 0.574 & 0.468 & 0.350 & 0.224 & 0.105 & 0.798 \\
\hline 2023 & 0.172 & 0.358 & 0.690 & 0.812 & 0.853 & 0.846 & 0.806 & 0.750 & 0.695 & 0.556 & 0.553 & 0.445 & 0.351 & 0.223 & 0.105 & 0.797 \\
\hline \multirow[t]{2}{*}{2024} & 0.172 & 0.362 & 0.688 & 0.812 & 0.853 & 0.846 & 0.803 & 0.750 & 0.696 & 0.559 & 0.532 & 0.428 & 0.350 & 0.225 & 0.105 & 0.797 \\
\hline & \multicolumn{16}{|c|}{ Absolute Change Due to Recession } \\
\hline 2007 & 0.000 & 0.000 & 0.000 & 0.000 & 0.000 & 0.000 & 0.000 & 0.000 & 0.000 & 0.000 & 0.000 & 0.000 & 0.000 & 0.000 & 0.000 & 0.000 \\
\hline 2008 & 0.000 & -0.061 & -0.039 & -0.025 & -0.003 & -0.010 & -0.010 & -0.010 & -0.027 & -0.011 & -0.010 & -0.010 & -0.010 & 0.000 & 0.000 & -0.012 \\
\hline 2009 & -0.016 & -0.128 & -0.171 & -0.075 & -0.044 & -0.032 & -0.014 & -0.012 & -0.010 & -0.029 & -0.010 & -0.010 & -0.010 & 0.000 & 0.000 & -0.051 \\
\hline 2010 & -0.018 & -0.184 & -0.245 & -0.079 & -0.049 & -0.045 & -0.024 & -0.028 & -0.020 & -0.049 & -0.010 & -0.010 & -0.014 & 0.000 & 0.000 & -0.063 \\
\hline 2011 & -0.017 & -0.187 & -0.244 & -0.072 & -0.027 & -0.044 & -0.020 & -0.042 & -0.038 & -0.051 & -0.010 & -0.010 & -0.010 & 0.000 & 0.000 & -0.051 \\
\hline 2012 & -0.019 & -0.173 & -0.215 & -0.060 & -0.010 & -0.038 & -0.009 & -0.038 & -0.031 & -0.048 & -0.010 & -0.010 & -0.010 & 0.000 & 0.000 & -0.036 \\
\hline 2013 & -0.011 & -0.153 & -0.184 & -0.050 & -0.010 & -0.031 & -0.010 & -0.022 & -0.025 & -0.037 & -0.010 & -0.010 & -0.010 & 0.000 & 0.000 & -0.031 \\
\hline 2014 & -0.003 & -0.138 & -0.156 & -0.041 & -0.010 & -0.025 & -0.010 & -0.010 & -0.010 & -0.024 & -0.010 & -0.010 & -0.010 & 0.000 & 0.000 & -0.027 \\
\hline 2015 & 0.000 & -0.124 & -0.131 & -0.033 & 0.000 & -0.021 & 0.000 & 0.000 & 0.000 & -0.012 & 0.000 & 0.000 & 0.000 & 0.000 & 0.000 & -0.017 \\
\hline 2016 & 0.000 & -0.114 & -0.111 & -0.027 & 0.000 & -0.017 & 0.000 & 0.000 & 0.000 & -0.003 & 0.000 & 0.000 & 0.000 & 0.000 & 0.000 & -0.014 \\
\hline 2017 & 0.000 & -0.109 & -0.098 & -0.023 & 0.000 & -0.017 & 0.000 & 0.000 & 0.000 & -0.003 & 0.000 & 0.000 & 0.000 & 0.000 & 0.000 & -0.013 \\
\hline 2018 & 0.000 & -0.108 & -0.094 & -0.021 & 0.000 & -0.014 & 0.000 & 0.000 & 0.000 & -0.010 & 0.000 & 0.000 & 0.000 & 0.000 & 0.000 & -0.012 \\
\hline 2019 & 0.000 & -0.107 & -0.094 & -0.021 & 0.000 & -0.012 & 0.000 & 0.000 & 0.000 & -0.012 & 0.000 & 0.000 & 0.000 & 0.000 & 0.000 & -0.012 \\
\hline 2020 & 0.000 & -0.107 & -0.094 & -0.021 & 0.000 & -0.010 & 0.000 & 0.000 & 0.000 & -0.013 & 0.000 & 0.000 & 0.000 & 0.000 & 0.000 & -0.012 \\
\hline 2021 & 0.000 & -0.108 & -0.093 & -0.021 & 0.000 & -0.010 & 0.000 & 0.000 & 0.000 & -0.016 & 0.000 & 0.000 & 0.000 & 0.000 & 0.000 & -0.012 \\
\hline 2022 & 0.000 & -0.110 & -0.093 & -0.021 & 0.000 & -0.011 & 0.000 & 0.000 & 0.000 & -0.017 & 0.000 & 0.000 & 0.000 & 0.000 & 0.000 & -0.012 \\
\hline 2023 & 0.000 & -0.110 & -0.094 & -0.021 & 0.000 & -0.011 & 0.000 & 0.000 & 0.000 & -0.016 & 0.000 & 0.000 & 0.000 & 0.000 & 0.000 & -0.012 \\
\hline 2024 & 0.000 & 0.000 & 0.000 & 0.000 & 0.000 & 0.000 & 0.000 & 0.000 & 0.000 & 0.000 & 0.000 & 0.000 & 0.000 & 0.000 & 0.000 & 0.000 \\
\hline
\end{tabular}

Source: Authors' calculations based on the 2008 and 2010 Social Security trustees' assumptions. 
Appendix Table 2. Female Employment Rates by Age and Year

\begin{tabular}{|c|c|c|c|c|c|c|c|c|c|c|c|c|c|c|c|c|}
\hline & \multicolumn{16}{|c|}{ Age } \\
\hline & 15 & 16 to 17 & 18 to 19 & 20 to 24 & 25 to 49 & 50 to 54 & 55 to 59 & 60 to 61 & 62 & 63 to 64 & 65 to 66 & 67 to 69 & $70-74$ & $75-79$ & 80-84 & 16-64 \\
\hline & \multicolumn{16}{|c|}{ Baseline Employment Rates } \\
\hline Year & & & & & & & & & & & & & & & & \\
\hline$\overline{2007}$ & 0.166 & 0.456 & 0.787 & 0.863 & 0.816 & 0.792 & 0.712 & 0.567 & 0.509 & 0.433 & 0.362 & 0.263 & 0.171 & 0.090 & 0.058 & 0.768 \\
\hline 2008 & 0.150 & 0.413 & 0.727 & 0.832 & 0.806 & 0.789 & 0.722 & 0.611 & 0.500 & 0.419 & 0.329 & 0.240 & 0.153 & 0.104 & 0.063 & 0.756 \\
\hline 2009 & 0.150 & 0.353 & 0.653 & 0.793 & 0.773 & 0.765 & 0.699 & 0.604 & 0.509 & 0.436 & 0.331 & 0.242 & 0.155 & 0.095 & 0.050 & 0.724 \\
\hline 2010 & 0.150 & 0.313 & 0.591 & 0.790 & 0.768 & 0.761 & 0.673 & 0.588 & 0.503 & 0.467 & 0.334 & 0.240 & 0.147 & 0.083 & 0.058 & 0.713 \\
\hline 2011 & 0.150 & 0.314 & 0.597 & 0.796 & 0.770 & 0.764 & 0.670 & 0.588 & 0.506 & 0.469 & 0.347 & 0.247 & 0.149 & 0.085 & 0.058 & 0.715 \\
\hline 2012 & 0.150 & 0.329 & 0.623 & 0.805 & 0.774 & 0.769 & 0.675 & 0.591 & 0.506 & 0.470 & 0.358 & 0.258 & 0.155 & 0.086 & 0.058 & 0.721 \\
\hline 2013 & 0.150 & 0.347 & 0.656 & 0.816 & 0.779 & 0.776 & 0.684 & 0.594 & 0.505 & 0.471 & 0.359 & 0.270 & 0.161 & 0.089 & 0.058 & 0.728 \\
\hline 2014 & 0.154 & 0.365 & 0.687 & 0.827 & 0.782 & 0.782 & 0.691 & 0.598 & 0.505 & 0.472 & 0.363 & 0.283 & 0.164 & 0.092 & 0.058 & 0.734 \\
\hline 2015 & 0.146 & 0.381 & 0.712 & 0.836 & 0.785 & 0.790 & 0.696 & 0.600 & 0.503 & 0.471 & 0.365 & 0.289 & 0.169 & 0.094 & 0.059 & 0.739 \\
\hline 2016 & 0.140 & 0.396 & 0.734 & 0.843 & 0.787 & 0.797 & 0.702 & 0.604 & 0.505 & 0.469 & 0.369 & 0.293 & 0.175 & 0.100 & 0.059 & 0.743 \\
\hline 2017 & 0.144 & 0.407 & 0.747 & 0.845 & 0.789 & 0.800 & 0.707 & 0.603 & 0.499 & 0.471 & 0.372 & 0.295 & 0.182 & 0.104 & 0.059 & 0.745 \\
\hline 2018 & 0.152 & 0.412 & 0.754 & 0.846 & 0.790 & 0.801 & 0.709 & 0.603 & 0.498 & 0.468 & 0.368 & 0.296 & 0.188 & 0.105 & 0.059 & 0.746 \\
\hline 2019 & 0.163 & 0.410 & 0.759 & 0.845 & 0.789 & 0.799 & 0.710 & 0.606 & 0.502 & 0.463 & 0.367 & 0.298 & 0.191 & 0.109 & 0.059 & 0.745 \\
\hline 2020 & 0.171 & 0.410 & 0.761 & 0.844 & 0.789 & 0.794 & 0.712 & 0.606 & 0.501 & 0.464 & 0.365 & 0.300 & 0.193 & 0.114 & 0.059 & 0.744 \\
\hline 2021 & 0.164 & 0.410 & 0.757 & 0.846 & 0.788 & 0.793 & 0.713 & 0.609 & 0.505 & 0.463 & 0.362 & 0.299 & 0.194 & 0.118 & 0.059 & 0.744 \\
\hline 2022 & 0.154 & 0.410 & 0.755 & 0.846 & 0.786 & 0.794 & 0.714 & 0.609 & 0.504 & 0.464 & 0.366 & 0.300 & 0.195 & 0.121 & 0.059 & 0.743 \\
\hline 2023 & 0.154 & 0.409 & 0.757 & 0.846 & 0.785 & 0.795 & 0.712 & 0.607 & 0.501 & 0.465 & 0.365 & 0.302 & 0.196 & 0.123 & 0.060 & 0.742 \\
\hline \multirow[t]{2}{*}{2024} & 0.153 & 0.415 & 0.755 & 0.847 & 0.784 & 0.795 & 0.710 & 0.606 & 0.503 & 0.462 & 0.365 & 0.305 & 0.196 & 0.124 & 0.060 & 0.742 \\
\hline & \multicolumn{16}{|c|}{ Absolute Change Due to Recession } \\
\hline 2007 & 0.000 & 0.000 & 0.000 & 0.000 & 0.000 & 0.000 & 0.000 & 0.000 & 0.000 & 0.000 & 0.000 & 0.000 & 0.000 & 0.000 & 0.000 & 0.000 \\
\hline 2008 & -0.020 & -0.051 & -0.020 & -0.002 & -0.010 & -0.010 & -0.010 & -0.010 & -0.011 & -0.016 & -0.038 & -0.027 & -0.024 & 0.000 & 0.000 & -0.011 \\
\hline 2009 & -0.017 & -0.133 & -0.121 & -0.038 & -0.020 & -0.022 & -0.010 & -0.010 & -0.010 & -0.010 & -0.053 & -0.038 & -0.027 & 0.000 & 0.000 & -0.030 \\
\hline 2010 & -0.014 & -0.190 & -0.208 & -0.037 & -0.024 & -0.024 & -0.010 & -0.010 & -0.010 & -0.010 & -0.052 & -0.043 & -0.042 & -0.005 & 0.000 & -0.038 \\
\hline 2011 & -0.014 & -0.190 & -0.205 & -0.032 & -0.021 & -0.020 & -0.010 & -0.010 & -0.010 & -0.010 & -0.032 & -0.028 & -0.042 & -0.004 & 0.000 & -0.035 \\
\hline 2012 & -0.014 & -0.173 & -0.174 & -0.030 & -0.016 & -0.013 & -0.010 & -0.010 & -0.010 & -0.010 & -0.017 & -0.013 & -0.039 & -0.004 & 0.000 & -0.029 \\
\hline 2013 & -0.011 & -0.152 & -0.139 & -0.029 & -0.010 & -0.006 & -0.010 & -0.010 & -0.010 & -0.010 & -0.017 & -0.010 & -0.040 & -0.002 & 0.000 & -0.023 \\
\hline 2014 & -0.010 & -0.132 & -0.106 & -0.026 & -0.010 & -0.010 & -0.010 & -0.010 & -0.010 & -0.010 & -0.010 & -0.010 & -0.047 & 0.000 & 0.000 & -0.021 \\
\hline 2015 & 0.000 & -0.115 & -0.078 & -0.020 & -0.001 & 0.000 & 0.000 & 0.000 & 0.000 & 0.000 & -0.002 & 0.000 & -0.046 & 0.000 & 0.000 & -0.011 \\
\hline 2016 & 0.000 & -0.101 & -0.055 & -0.013 & 0.000 & 0.000 & 0.000 & 0.000 & 0.000 & 0.000 & -0.004 & 0.000 & -0.040 & 0.000 & 0.000 & -0.008 \\
\hline 2017 & 0.000 & -0.092 & -0.040 & -0.009 & 0.000 & 0.000 & 0.000 & 0.000 & 0.000 & 0.000 & -0.007 & 0.000 & -0.036 & 0.000 & 0.000 & -0.006 \\
\hline 2018 & 0.000 & -0.088 & -0.034 & -0.007 & 0.000 & 0.000 & 0.000 & 0.000 & 0.000 & 0.000 & -0.010 & 0.000 & -0.036 & 0.000 & 0.000 & -0.006 \\
\hline 2019 & 0.000 & -0.086 & -0.032 & -0.006 & 0.000 & 0.000 & 0.000 & 0.000 & 0.000 & 0.000 & -0.010 & 0.000 & -0.036 & 0.000 & 0.000 & -0.005 \\
\hline 2020 & 0.000 & -0.086 & -0.031 & -0.006 & 0.000 & 0.000 & 0.000 & 0.000 & 0.000 & 0.000 & -0.014 & 0.000 & -0.035 & 0.000 & 0.000 & -0.006 \\
\hline 2021 & 0.000 & -0.086 & -0.031 & -0.005 & -0.001 & 0.000 & 0.000 & 0.000 & 0.000 & 0.000 & -0.019 & 0.000 & -0.035 & 0.000 & 0.000 & -0.006 \\
\hline 2022 & 0.000 & -0.089 & -0.030 & -0.005 & -0.002 & 0.000 & 0.000 & 0.000 & 0.000 & 0.000 & -0.017 & 0.000 & -0.034 & 0.000 & 0.000 & -0.006 \\
\hline 2023 & 0.000 & -0.089 & -0.031 & -0.005 & -0.003 & 0.000 & 0.000 & 0.000 & 0.000 & 0.000 & -0.022 & 0.000 & -0.033 & 0.000 & 0.000 & -0.007 \\
\hline 2024 & 0.000 & 0.000 & 0.000 & 0.000 & 0.000 & 0.000 & 0.000 & 0.000 & 0.000 & 0.000 & 0.000 & 0.000 & 0.000 & 0.000 & 0.000 & 0.000 \\
\hline
\end{tabular}




\section{RECENT WORKING PAPERS FROM THE}

\section{CENTER FOR RETIREMENT RESEARCH AT BOSTON COLLEGE}

Immigrant Diversity and Social Security: Recent Patterns and Future Prospects Melissa M. Favreault and Austin Nichols, May 2011

Why Aren't More Families Buying Life Insurance?

Matthew S. Chambers, Don E. Schlagenhauf, and Eric R. Young, March 2011

Changes in Firm Pension Policy: Trends Away From Traditional Defined Benefit Plans Kandice A. Kapinos, February 2011

Interdependent Durations in Joint Retirement

Bo Honoré and Áureo de Paula, February 2011

Health and Retirement Effects in a Collective Consumption Model of Elderly Households Arthur Lewbel and Shannon Seitz, February 2011

Age Differences in Job Displacement, Job Search, and Reemployment

Richard W. Johnson and Corina Mommaerts, January 2011

The Earnings and Social Security Contributions of Documented and Undocumented Mexican Immigrants

Gary Burtless and Audrey Singer, January 2011

How Important Are Intergenerational Transfers for Baby Boomers?

Alicia H. Munnell, Anthony Webb, Zhenya Karamcheva, and Andrew Eschtruth, January 2011

Effect of Informal Care on Work, Wages, and Wealth

Courtney Harold Van Houtven, Norma B. Coe, and Meghan Skira, December 2010

Recessions, Wealth Destruction, and the Timing of Retirement

Barry P. Bosworth and Gary Burtless, December 2010

Measuring the Spillover to Disability Insurance Due to the Rise in the Full Retirement Age Norma B. Coe and Kelly Haverstick, December 2010

Is the Reduction in Older Workers' Job Tenure a Cause for Concern?

Steven A. Sass and Anthony Webb, December 2010

Accounting for Disability Insurance in the Dynamic Relationship Between Disability Onset and Earnings

Perry Singleton, November 2010

All working papers are available on the Center for Retirement Research website (http://crr.bc.edu) and can be requested by e-mail (crr@bc.edu) or phone (617-552-1762). 